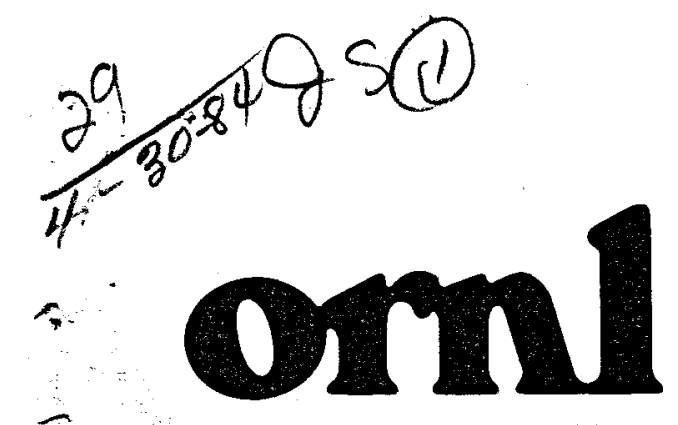

$\div$

OAK

RIDGE

NATIONAL

LABORATORY

UNION

CARBIDE

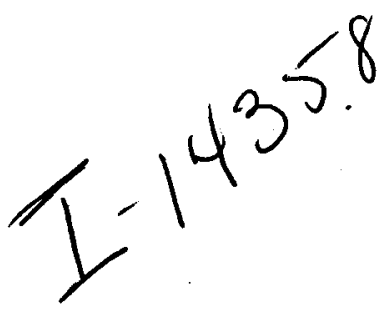

ORNL/TH-9071
Retrospective Examination of Geothermal Environmental Assessments

J. W. Webb

G. K. Eddlemon

A. W. Reed

DO NOT MICROFILI:
COVER
OPERATED BY

UNION CARBIDE CORPORATION FOR THE UNITED STATES DEPARTMENT OF ENERGY 


\section{DISCLAIMER}

This report was prepared as an account of work sponsored by an agency of the United States Government. Neither the United States Government nor any agency Thereof, nor any of their employees, makes any warranty, express or implied, or assumes any legal liability or responsibility for the accuracy, completeness, or usefulness of any information, apparatus, product, or process disclosed, or represents that its use would not infringe privately owned rights. Reference herein to any specific commercial product, process, or service by trade name, trademark, manufacturer, or otherwise does not necessarily constitute or imply its endorsement, recommendation, or favoring by the United States Government or any agency thereof. The views and opinions of authors expressed herein do not necessarily state or reflect those of the United States Government or any agency thereof. 


\section{DISCLAIMER}

Portions of this document may be illegible in electronic image products. Images are produced from the best available original document. 


\section{Printed in the United States of America. Available from}

National Technical Information Service

U.S. Department of Commerce

5285 Port Royal Road, Springfield, Virginia 22161

NTIS price codes-Printed Copy: A05; Microfiche A01

This report was prepared as an account of work sponsored by an agency of the United States Government. Neither the United States Government nor any agency thereof, nor any of their employees, makes any warranty, express or implied, or assumes any legal liability or responsibility for the accuracy, completeness, or usefulness of any information, apparatus, product, or process disclosed, or represents that its use would not infringe privately owned rights. Reference herein to any specific commercial product, process, or service by trade name, trademark, manufacturer, or otherwise, does not necessarily constitute or imply its endorsement. recommendation, or favoring by the United States Government or any agency thereof. The views and opinions of authors expressed herein do not necessarily state or reflect those of the United States Government or any agency thereof.

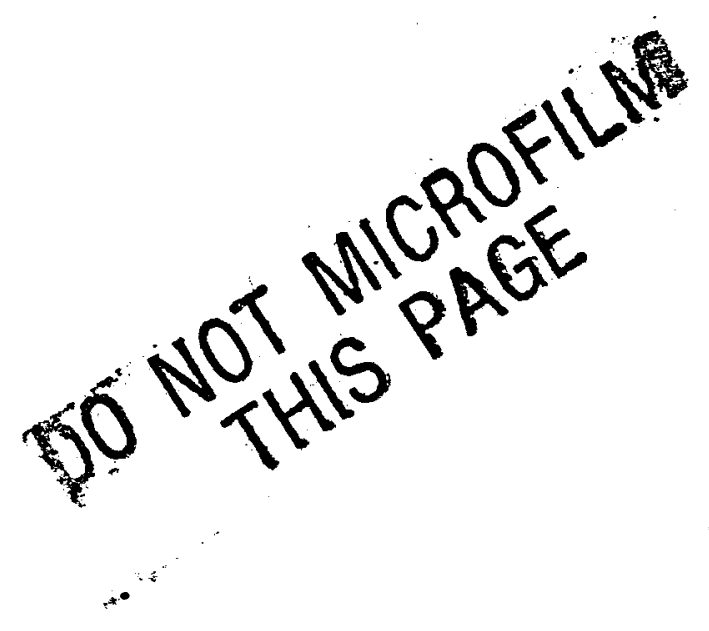


ORNL/TM- -9071

DE84 010615

\author{
ENVIRONMENTAL SCIENCES DIVISION \\ ENERGY DIVISION
}

\title{
RETROSPECTIVE EXAMINATION OF GEOTHERMAL ENVIRONMENTAL ASSESSMENTS
}

\author{
J. W. Webb' \\ G. K. Eddlemon * \\ A. W. Reed ${ }^{\dagger}$ \\ Environmental Sciences Division. \\ tEnergy Division.
}

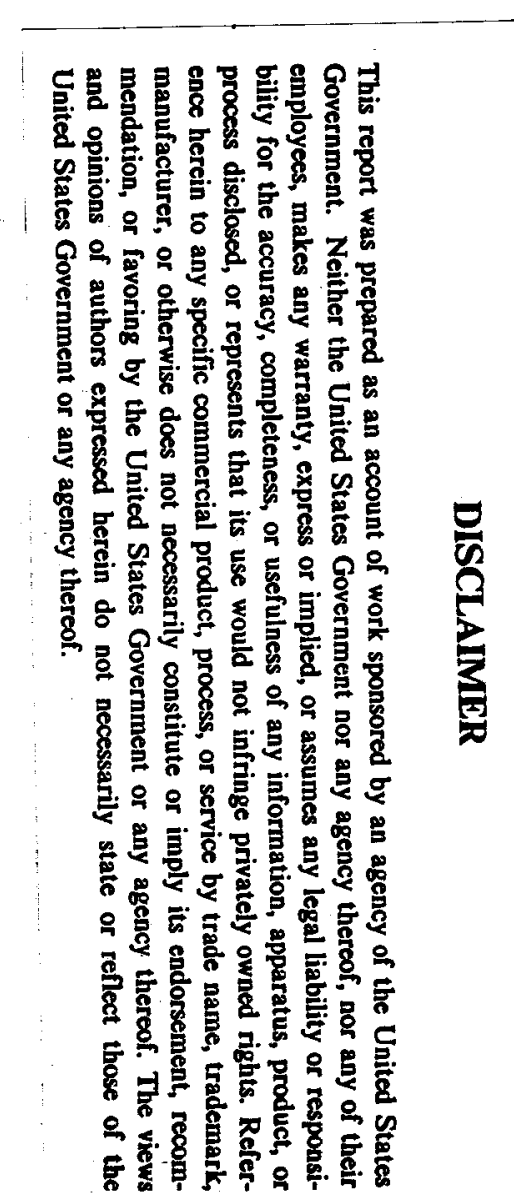

Date of Issue-March 1984

Prepared by the

OAK RIDGE NATIONAL LABORATORY

Oak Ridge, Tennessee 37831 operated by UNION CARBIDE CORPORATION for the U.S. DEPARTMENT OF ENERGY under Contract No. W-7405-eng-26 



\section{CONTENTS}

ABBREVIATIONS AND ACRONYMS $\ldots \ldots \ldots \ldots \ldots \ldots \ldots \ldots \ldots \ldots \ldots \ldots \ldots$

ACKNOWLEDGMENTS $\ldots \ldots \ldots \ldots \ldots \ldots \ldots \ldots \ldots \ldots \ldots \ldots \ldots \ldots \ldots \ldots \ldots \ldots$ vii

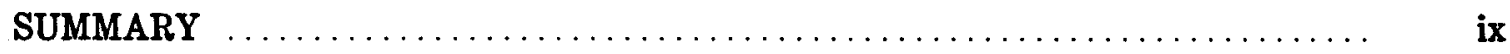

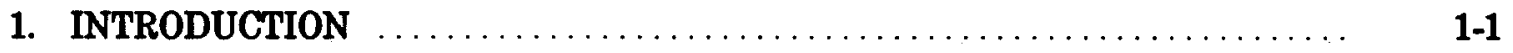

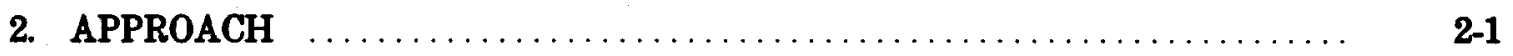

3. REVIEW OF DOE GEOTHERMAL DOCUMENTS $\ldots \ldots \ldots \ldots \ldots \ldots \ldots \ldots$

3.1 PREDICTED ENVIRONMENTAL EFFECTS $\ldots \ldots \ldots \ldots \ldots \ldots \ldots \ldots \ldots, \quad 3-1$

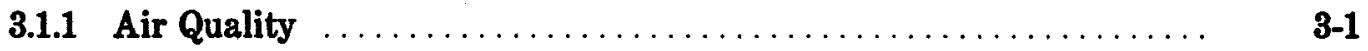

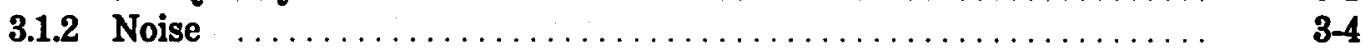

3.1.3 Groundwater, Geology, and Soils ................. 3-5

3.1.4 Surface Waters and Aquatic Ecology $\ldots \ldots \ldots \ldots \ldots \ldots \ldots \ldots \ldots . . \ldots \ldots$

3.1.5 Land Use and Terrestrial Ecology $\ldots \ldots \ldots \ldots \ldots \ldots \ldots \ldots \ldots \ldots$

3.1.6 Cultural and Socioeconomic $\ldots \ldots \ldots \ldots \ldots \ldots \ldots \ldots \ldots \ldots \ldots$

3.2 RECOMMENDED MONITORING AND MITIGATION MEASURES .....

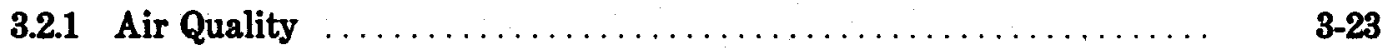

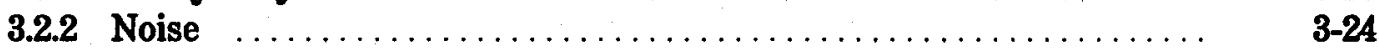

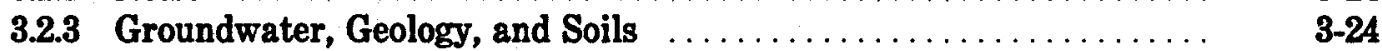

3.2.4 Surface Waters and Aquatic Ecology $\ldots \ldots \ldots \ldots \ldots \ldots \ldots \ldots \ldots$

3.2.5 Land Use and Terrestrial Ecology . . . . . . . . . . . . . . . . . . . . .

3.2.6 Cultural and Socioeconomic $\ldots \ldots \ldots \ldots \ldots \ldots \ldots \ldots \ldots \ldots \ldots, \ldots \ldots$

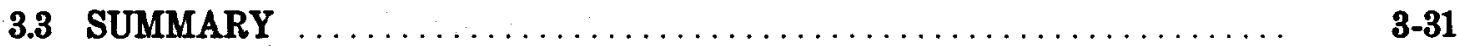

4. CURRENT STATUS AND ENVIRONMENTAL CONCERNS OF

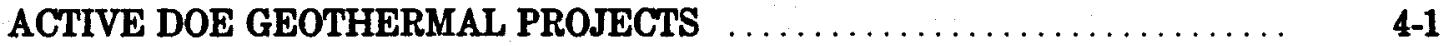

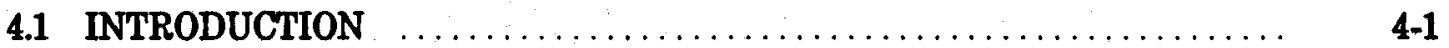

4.2 CURRENT STATUS OF DOE GEOTHERMAL PROJECTS $\ldots \ldots \ldots \ldots \ldots$ 4-1

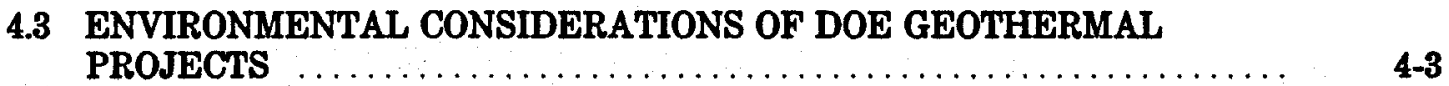

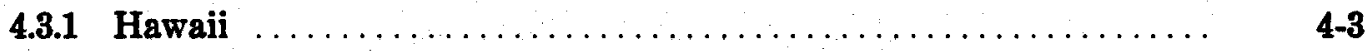

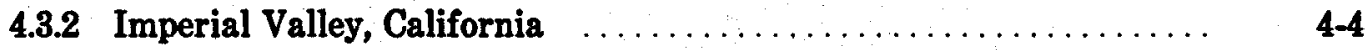

4.3.3 Geopressure Projects, Texas and Louisiana $\ldots \ldots \ldots \ldots \ldots \ldots \ldots, \quad 4.5$

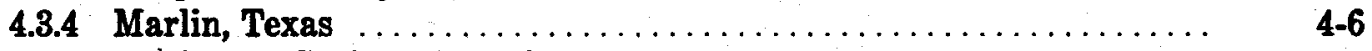

4.3.5 Brady Hot Springs, Nevada $\ldots \ldots \ldots \ldots \ldots \ldots \ldots \ldots \ldots \ldots \ldots \ldots$ 4 4

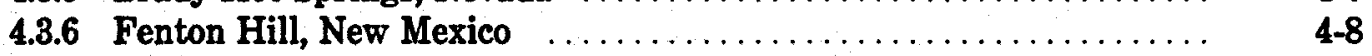

4.3.7 Boise Geothermal Limited, Idaho ................... 4-10

4.3.8 Northern California Power Agency No. 2 (NCPA No. 2) ........ 4-11

4.3.9 Raft River, Idaho $\ldots \ldots \ldots \ldots \ldots \ldots \ldots \ldots \ldots \ldots \ldots \ldots \ldots \ldots . \ldots \ldots$

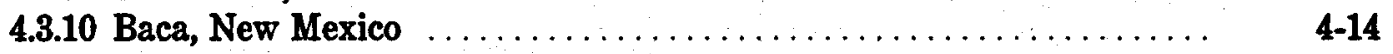

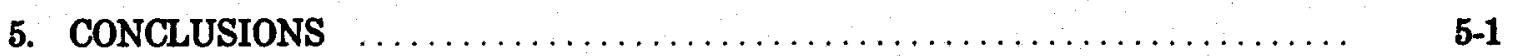

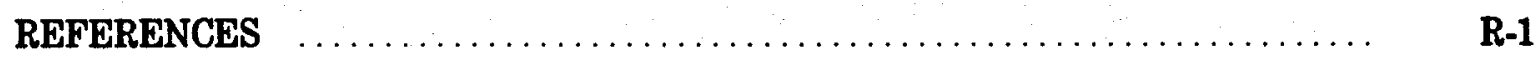

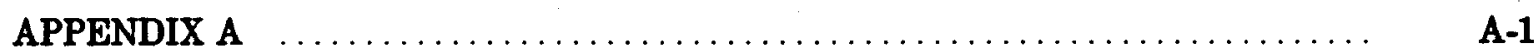

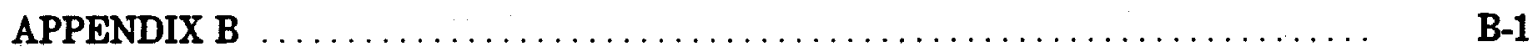




\section{ABBREVIATIONS AND ACRONYMS}

DOE Department of Energy

EA Environmental Assessment

EIS Environmental Impact Statement

GHTD Geothermal and Hydropower Technologies Division

JES Joint Environmental Study

NEPA National Environmental Policy Act

ORNL Oak Ridge National Laboratory

PSD Prevention of Significant Deterioration

SAN San Francisco Operations Office

TDS Total Dissolved Solids

TSS Total Suspended Solids 



\section{ACKNOWLEDGMENTS}

The authors express their appreciation to J. S. Baldwin, C. R. Boston, R. B. Braid, Jr., R. M. Cushman, S. G. Hildebrand, D. B. Hunsaker, F. C. Kornegay, W. P. Staub, L. D. Voorhees, and H. E. Zittel for their critical review of all or a portion of this manuscript, Publication No. 2290 of the Environmental Sciences Division, Oak Ridge National Laboratory (ORNL). We also thank R. K. Oran of the Environmental Sciences Division, ORNL, for typing the manuscript and T. Truett of the Energy Division Publications Office, ORNL, for editorial assistance. 


\section{SUMMARY}

Since 1976, the Department of Energy (DOE) has supported a variety of programs and projects dealing with the exploration, development, and utilization of geothermal energy. This report presents an overview of the environmental impacts associated with these efforts. Impacts that were predicted in the environmental analyses prepared for the programs and projects are reviewed and summarized, along with measures that were recommended to mitigate these impacts. Also, for those projects that have gone forward, actual impacts and implemented mitigation measures are reported, based on telephone interviews with DOE and project personnel.

In general, both predicted and actual environmental impacts of geothermal projects were minor. In comparison with most other energy technologies, fewer impacts occurred, and those that did were usually not serious. Moreover, most recommended mitigation measures were implemented and played an important role in lessening the severity of impacts. This finding emphasizes the importance of early environmental analysis and planning with subsequent monitoring and verification.

An accident involving spills of geothermal fluids was the major environmental concern associated with geothermal development. Other important considerations included noise from drilling and production, emissions of $\mathrm{H}_{2} \mathrm{~S}$ and cooling tower drift, disposal of solid waste (e.g., from $\mathrm{H}_{2} \mathrm{~S}$ control), and the cumulative effects of geothermal development on land use and ecosystems. Mitigation measures were frequently recommended and implemented in conjunction with noise reduction; drift elimination; reduction of fugitive dust, erosion, and sedimentation; blowout prevention; and retention of wastes and spills. Monitoring to resolve uncertainties was often implemented to detect induced seismicity and subsidence, noise, drift deposition, concentrations of air and water pollutants, and effects on groundwater.

The document contains an appendix, based on these findings, which outlines major environmental concerns, mitigation measures, and monitoring requirements associated with geothermal energy. Sources of information on various potential impacts are also listed. 


\section{INTRODUCTION}

In 1976, the U.S. Energy Research and Development Administration [now the Department of Energy (DOE)], Division of Geothermal Energy [now the Geothermal and Hydropower Technologies Division (GHTD)], established a number of programs intended to encourage the exploration, development, and use of geothermal energy. The programs focused on (1) various forms of geothermal energy (hydrothermal, hot dry rock, and geopressured geothermal subprograms), (2) geothermal exploratory drilling, and (3) geothermal loan guaranties to assist commercial development. In conjunction with these programs and their associated projects, a series of programmatic and site- or area-specific environmental documents was prepared to ensure protection of the environment and satisfy the requirements of the National Environmental Policy Act (NEPA). The documents were either prepared or reviewed by technical staff members of Oak Ridge National Laboratory (ORNL) and represent more than six years of experience by GHTD and ORNL in dealing with environmental concerns related to geothermal energy.

In the light of this experience, there is a need to synthesize and assess the NEPA environmental assessments (EAs) and subsequently implemented monitoring and mitigation. Such an effort would provide a comprehensive perspective on environmental concerns to assist in future programmatic planning and technology transfer to both the public and private sectors. The work was conducted in three phases. In Phase I, the existing environmental analyses were reviewed for predicted environmental impacts and recommended mitigation and monitoring. Phase II entailed an update on the status of currently active site-specific projects. Phase III was a survey to ascertain actual impacts and implemented mitigation measures for projects that have gone forward. In addition to the results of these three phases, the current document includes a discussion of actual project impacts and, in Appendix $B$, a summary outline of environmental concerns. 


\section{APPROACH}

The review and evaluation was conducted by a multidisciplinary team at ORNL. In Phase I, both programmatic and site- or area-specific environmental documents were reviewed (Table 2.1). The documents cover projects located in seven western states, two south-central states and the eastern piedmont and coastal plain region, providing broad, representative geographical coverage of geothermal resources in the United States.

The results of the review are reported in Sect. 3 by subject area. To avoid unnecessary repetition, impacts discussed in programmatic documents are either summarized separately as generic impacts or integrated with a discussion of project-specific impacts. References to programmatic or site-specific environmental analyses are indicated by numbers in brackets, which are keyed to the full citations found in Appendix A. The presentation of results in the various subject areas varies somewhat according to the nature of the material.

The current status of projects reviewed in Phase $I$ was ascertained through consultation with DOE staff in GHTD in Washington, D.C., and in the DOE San Francisco Operations Office (SAN). Individuals contacted include the following:

- Pauline A. LaBrie, GHTD

- Denis J. Feck, GHTD

- Allan J. Jelacic, GHTD

- Gwendolyn K. Redding, GHTD

- David B. Lombard, GHTD

- Gerald Katz, SAN

- Martin W. Molloy, SAN

- Edward Dickenson, SAN

For the geopressured geothermal projects, managers for operating contractors were also contacted, in conjunction with decommissioning verification performed for GHTD. Details of the verification of geopressure environmental impacts can be found in Reed et al. (1983). The results of Phase II are reported below in Sect. 4.2.

Individuals contacted by telephone to determine actual impacts and mitigation measures for existing projects are given in Table 2.2. The results of this survey are reported by project in Sect. 4.2. Section 5 presents (1) summaries of actual vs predicted impacts and recommended mitigation measures and (2) generalizations on environmental impacts of geothermal energy. References are cited in the text by the author-date method, and complete sources are given in the Reference list. Environmental concerns are summarized in an outline presented in Appendix B. 
Table 2.1. Summary titles of programmatic and site- or area-specific environmental documents reviewed ${ }^{a}$

Programmatic/subprogrammatic

Hydrothermal Subprogram, EIA/GE/77-2

Hot Dry Rock Subprogram, EIA/GE/77-6

Geopressure Subprogram, EIA/GE/77-3

Geopressure Subprogram, Frio formation, DOE/EA-0023

Geopressure Subprogram, Wilcox and Tuscaloosa formations (DOE 1979)

Geopressure Exploratory Drilling, eastern United States, DOE/EA-0015

Geopressure site/area specific projects

Pleasant Bayou, Texas, DOE/EA-0013

Sweet Lake, Louisiana, DOE/EA-0065

Gladys McCall, Louisiana, DOE/EA-0134

Dow Parcperdue, Louisiana (DOE 1980)

LaFourche Crossing Prospect, Louisiana (DOE 1978)

Southeast Pecan Island Prospect, Louisiana (DOE 1979)

Blessing Prospect, Texas (DOE 1981)

Hydrothermal site/area specific projects

Hawaii Well Flow Test (ERDA 1976)

Hawaii Research Station, DOE/EA-0071

Raft River Test Loop, Idaho, DOE/EA-0008

Raft River Pilot Plant, Idaho, DOE/EA-0090

Coso (China Lake) Well Test, California, DOE/EA-0036

Baca Ranch Demonstration Plant, New Mexico, DOE/EIS-0049

Marlin Direct Heat, Texas, DOE/EA-0117

Heber Demonstration Plant, California, DOE/EA-0119

Brady Hot Springs Food Processing, Nevada, ELA/GE/77-5

South Brawley Project, California, EIA/GE/77-7

Beryl and Lund Project, Utah, EIA/GE/77-8

Roosevelt Hot Springs Field Development, Utah (DOE 1978)

Westmorland Development Project, California, DOE/EA-0058

Oregon Trail Mushrooms, Oregon, DOE/EA-0103

Northern California Power Agency (NCPA) No. 2, California ${ }^{b}$

Rorabaugh Lease Development, California (DOE 1981)

Republic East Mesa (DOE 1979)

Boise District Heating (DOE 1981)

Hot dry rock specific project

Fenton Hill, New Mexico, DOE/EA-0091

agency and date are given when documents are in draft or other unnumbered form. Complete citations are in Appendix A.

Worthern California Power Agency, NCPA Na \& Geothermal Power Plant, Final Joint Envirommental Study, March 1980. 
Table 2.2. Contacts made regarding environmental concerns of existing DOE geothermal projects

\begin{tabular}{|c|c|c|}
\hline Project(s) & Name & Affiliation \\
\hline Hawaii Research Station & $\begin{array}{l}\text { Gerald Katz } \\
\text { Susan V. Cook } \\
\text { Louis Lopez } \\
\text { Donald Thomas }\end{array}$ & $\begin{array}{l}\text { DOE, San Francisco Operations } \\
\text { U.S. Department of Justice, } \\
\text { Washington, D.C. } \\
\text { University of Hawaii } \\
\text { University of Hawaii }\end{array}$ \\
\hline $\begin{array}{l}\text { Imperial Valley projects } \\
\text { (East Mesa, South Brawley, } \\
\text { Westmorland, Heber) }\end{array}$ & $\begin{array}{l}\text { Philip Shaffer } \\
\text { Claude M. Finnell } \\
\text { Harry Hanson } \\
\text { Kenneth Landau } \\
\text { Daniel Bell } \\
\text { Anthony J. Adduci } \\
\text { Jerald Scheinberg } \\
\text { William Holman } \\
\text { Richard Corbaley } \\
\text { Sean Haggerty } \\
\text { Patrick Welch }\end{array}$ & $\begin{array}{l}\text { Imperial County Planning } \\
\text { Commission, El Centro, California } \\
\text { Imperial County Air Pollution } \\
\text { Control District, El Centro, California } \\
\text { California Water Resources } \\
\text { Control Board, El Centro, California } \\
\text { California Water Resources } \\
\text { Control Board, El Centro, California } \\
\text { California Office of Historic } \\
\text { Preservation, Sacramento, California } \\
\text { DOE San Francisco Operations } \\
\text { DOE San Francisco Operations } \\
\text { DOE San Francisco Operations } \\
\text { California Division of Oil and } \\
\text { Gas, El Centro, California } \\
\text { Bureau of Land Management } \\
\text { Menlo Park, California } \\
\text { Bureau of Land Management } \\
\text { El Centro, California }\end{array}$ \\
\hline $\begin{array}{l}\text { Geopressure projects } \\
\text { (Pleasant Bayou, Dow } \\
\text { Parcperdue, Sweet Lake, } \\
\text { Gladys McCall) }\end{array}$ & $\begin{array}{l}\text { Virginia R. Van Sickle } \\
\text { Myron H. Dorfman } \\
\text { Kenneth Gray }\end{array}$ & $\begin{array}{l}\text { Louisiana Geological Survey, } \\
\text { Baton Rouge, Louisiana } \\
\text { University of Texas, Austin } \\
\text { University of Texas, Austin }\end{array}$ \\
\hline Fenton Hill & $\begin{array}{l}\text { Kenneth H. Rea } \\
\text { Melvin L. MeCorkle } \\
\text { Greg Nunz } \\
\text { Paul Franke } \\
\text { S. E. Reynolds } \\
\text { Joe D. Ramey } \\
\text { Oscar A. Simpson } \\
\text { Byron Donaldson }\end{array}$ & $\begin{array}{l}\text { Los Alamos National Laboratory } \\
\text { Los Alamos National Laboratory } \\
\text { Los Alamos National Laboratory } \\
\text { Los Alamos National Laboratory } \\
\text { New Mexico State Engineer } \\
\text { New Mexico Energy and Minerals } \\
\text { Development } \\
\text { New Mexico Environmental } \\
\text { Improvement Division } \\
\text { New Mexico Game and } \\
\text { Fish Department }\end{array}$ \\
\hline Brady Hot Springs & $\begin{array}{l}\text { Estela Romo } \\
\text { Ralph G. Capurro }\end{array}$ & $\begin{array}{l}\text { DOE, San Francisco Operations } \\
\text { Nevada Department of Conservation } \\
\text { and Natural Resources }\end{array}$ \\
\hline Marlin & $\begin{array}{l}\text { Robert D. Clarke } \\
\text { Marshall F. Conover }\end{array}$ & $\begin{array}{l}\text { DOE, Las Vegas, Nevada, Operations } \\
\text { Radian Corp., Austin, Texas }\end{array}$ \\
\hline
\end{tabular}


Table 2.2 (continued)

\begin{tabular}{|c|c|c|}
\hline Project(s) & Name & Affiliation \\
\hline Boise Geothermal & $\begin{array}{l}\text { Phillip Hanson } \\
\text { Carl B. Ellsworth } \\
\text { Andrew Lermer } \\
\text { Darrel Clapp } \\
\text { Frank W. Childs } \\
\text { Susan M. Prestwich } \\
\text { Larry M. Fettkether } \\
\text { Jerry Yoder } \\
\text { Jack E. Kelly } \\
\text { Monte R. Richards }\end{array}$ & $\begin{array}{l}\text { City of Boise } \\
\text { City of Boise } \\
\text { City of Boise } \\
\text { Idaho Department of Natural Resources } \\
\text { EG\&G Idaho Inc. } \\
\text { DOE, Idaho Operations } \\
\mathrm{CH}_{2} \mathrm{M} \text { Hill Inc.-Boise } \\
\text { Idaho Department of Health and Welfare } \\
\text { Anderson and Kelly, Inc., } \\
\text { Boise, Idaho } \\
\text { Idaho Fish and Game Department }\end{array}$ \\
\hline NCPA No. 2 & $\begin{array}{l}\text { James W. Whalen } \\
\text { Michael A. Argentine } \\
\text { David M. Snetsinger } \\
\text { Sean Connally } \\
\text { William J. Stech } \\
\text { Edward Dickenson } \\
\text { Theodore W. Wooster } \\
\text { Robert C. Karfiol }\end{array}$ & $\begin{array}{l}\text { Northern California Municipal } \\
\text { Power Corporation } \\
\text { Northern California Municipal } \\
\text { Power Corporation } \\
\text { California Water Quality Control } \\
\text { Board, North Coast Region } \\
\text { North Sonoma County Air Pollution } \\
\text { Control District } \\
\text { North Sonoma County Air Pollution } \\
\text { Control District } \\
\text { DOE, San Francisco Operations } \\
\text { California Department of Fish and Game } \\
\text { Pacific Gas and Electric, } \\
\text { San Ramon, California }\end{array}$ \\
\hline
\end{tabular}




\section{REVIEW OF DOE GEOTHERMAL NEPA DOCUMENTS}

\subsection{PREDICTED ENVIRONMENTAL EFFECTS}

\subsubsection{Air Quality}

\subsubsection{Generic impacts}

Air quality impacts of geothermal energy development may occur during well drilling and testing, construction of utilization facilities, and operation of a power plant or processing facility. The potential effects of activities in DOE's geopressure, hydrothermal, hot dry rock, and exploratory well drilling programs were described generically in environmental documents prepared for each program $[2,10,12,13]$.* With regard to air quality, potential impacts of activities among these programs were similar.

In some cases, impacts of geothermal energy differ qualitatively and quantitatively from those of other energy resources. In general, geothermal air quality impacts are considered more benign. Some impacts, however, are unique to geothermal systems and can be environmentally costly if unmitigated. Such instances are noted in the discussion below.

\section{Well drilling and testing}

During resource exploration, DOE predicted minor impacts from gaseous emissions from vehicles and equipment (e.g., diesel generators), from fugitive dust from unpaved roads, and from movement of earth during clearing and excavation of a site. Such impacts are not unique to geothermal projects. During well drilling and subsequent testing, air quality can be impacted by geothermal brine and steam released to the atmosphere when the well is vented. In most hydrothermal and geopressure systems, gases present in the brine/steam may be emitted. Gases that may be released include carbon dioxide, carbon monoxide, hydrogen sulfide, methane, nitrogen, ammonia, and trace amounts of argon, hydrogen fluoride, and sulfur dioxide. Dissolved mineral salts of boron, mercury, and arsenic may also occur (Hartley 1978). Hydrogen sulfide is the principal air pollutant of concern because of its frequent occurrence in geothermal systems and its nuisance odor at low concentrations (between 1 and $30 \mathrm{ppb}$ ). The potential toxicity at levels above 10 ppm was also mentioned in the EAs. Because the composition and concentration of these gases vary among geothermal resources, site-specific chemical analyses are necessary for impact prediction, often followed by modeling of transport and deposition. In addition to the gases, uncontrolled high levels of water vapor emitted during well testing could affect the local climate, particularly in arid regions.

\footnotetext{
* Numbers in brackets refer to various EAs, whose complete documentation is given in Appendix A. Other references and sources are cited by the author-date method, and the complete source is given in the References.
} 
Air quality impacts of energy extraction from hot dry rock are minimal because geothermal brine/steam is not produced. The composition of water injected into hot dry rock reservoirs to produce steam or hot water is controlled by the developer and should not contain the noncondensable gases listed above.

\section{Facilities-construction and use}

Construction of geothermal facilities (e.g., power plant, transmission lines, and pipelines) causes impacts similar to those of construction during well drilling and testing (e.g., fugitive dust and gaseous emissions). Air pollutants likely to result from operation of geothermal energy facilities may arise from cooling tower operation, intermittent venting of production wells, and accidents. The quantity of pollutants emitted will vary according to the technology used (e.g.; open and closed flash and binary cycles) (Nguyen et al. 1980, Beeland and Boies 1981). Of primary concern are dissolved solids in cooling tower drift and hydrogen sulfide in the geothermal brine/steam. Both potential pollutants are relatively unique to geothermal resource development: the solids, because they reflect the chemistry of the geothermal resource, including potentially toxic salts of boron, mercury, and arsenic; the hydrogen sulfide, because of its natural occurrence. Of lesser concern is water vapor produced in cooling tower operation, which could affect the local climate. These impacts are more likely to occur as a result of hydrothermal and geopressured geothermal resource utilization, rather than hot dry rock, for reasons cited earlier.

Direct heat and processing applications of geothermal energy are expected to produce little impact on air quality except from venting of production wells and from pipeline rupture or other accidents that could release hydrogen sulfide to the atmosphere.

In most cases, air pollutants from development and utilization of geothermal resources can be reduced to levels at which there will be no significant environmental impact. Measures to accomplish this are discussed in Sect. 3.2.1.

\subsubsection{Site-specific impacts}

A review of site-specific environmental documents indicated that air quality impacts from specific geothermal projects were predicted to be minor, short-term, and insignificant for most projects assessed. The nature and severity of site-specific air quality impacts depended on the nature of the geothermal resource, the utilization processes and facilities employed, and the mitigation measures implemented.

A summary of predicted air quality impacts for specific projects is presented in Table 3.1. The following discussion highlights certain aspects of the air quality impact analyses.

Of the geothermal loan guaranty projects reviewed, the proposed power plants in the Geysers area of northern California (Rorabaugh and NCPA No. 2 Loan Guaranty projects) had the greatest potential for air impacts because of the relatively high concentrations of hydrogen sulfide occurring in the resource. All loan 
Table 3.1 Summary of air quality impacts prodictod for DOE geothormal projects

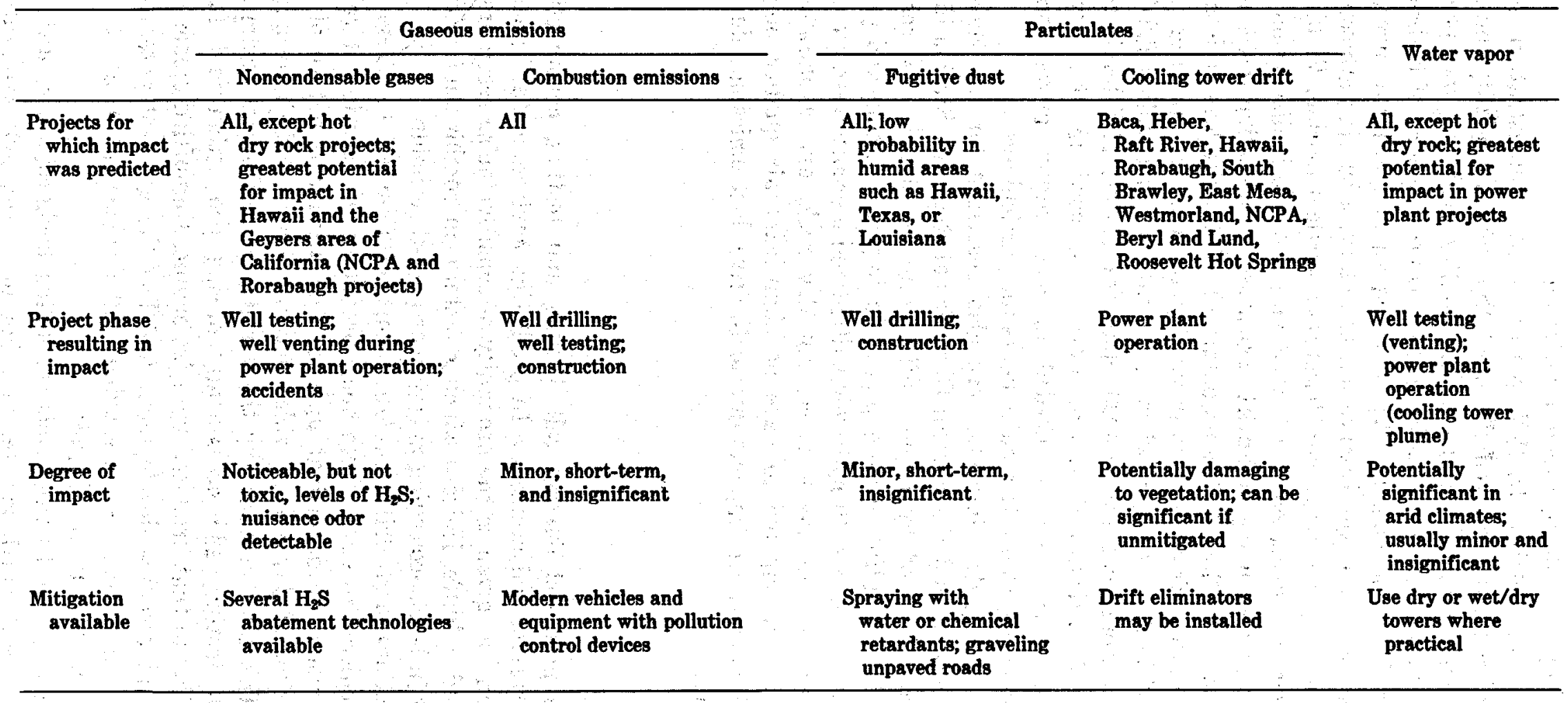


guaranty projects were predicted to have slight construction and drill-site preparation impacts resulting from fugitive dust.

The Baca and Heber 50-MW power plant demonstration projects of the hydrothermal program received the most thorough air quality impact assessments of all DOE environmental projects. Air quality modeling was performed for the Baca project to predict increases in ambient concentrations of hydrogen sulfide. The results from the Baca modeling [7] indicated an insignificant increase in hydrogen sulfide concentration at the reservation boundary, assuming atmospheric conditions that would neither encourage nor discourage vertical motion. Violations of ambient standards were not expected. For Heber, an atmospheric dispersion model was used to provide estimates of fog and drift deposition from cooling tower operation. Those results [9] indicated that drift eliminators ( $0.008 \%$ drift loss or less) would prevent significant impacts from increased salinity from drift deposition during the first five years of plant operation when the total dissolved solids (TDS) levels in the cooling water would not exceed $4000 \mathrm{ppm}$. Thereafter, TDS levels could increase to $20,000 \mathrm{ppm}$ if agricultural return flow were used in the towers. Additional mitigation measures may be needed to meet future prevention of significant deterioration (PSD) Class II requirements for particulates.

Potential air quality impacts were also described for the Hawaii Geothermal Well Test Flow [1] and the Hawaii Geothermal Research Station [5] because of the high concentrations of hydrogen sulfide and mercury in the resource. Nuisance levels of hydrogen sulfide were expected during well testing and production at this site, and monitoring of both hydrogen sulfide and mercury were recommended.

All projects of the geopressure, hot dry rock, and exploratory well drilling programs were anticipated to have no significant air quality impacts, with only minor, local, short-term impacts due to fugitive dust emissions during construction and operation.

\subsubsection{Noise}

Noise is produced during well drilling and testing, construction of facilities, facility operation, and accidents. In predicting environmental impacts due to noise, consideration was given to the proximity of sensitive noise receptors, such as nearby residents and wildlife. Noise-producing factors, in combination with existing noise, could result in levels exceeding nuisance or pain-thresholds.

Construction- and drilling-related impacts (similar to those of oil and gas drilling) predicted to result from noise produced by operation of vehicles and heavy equipment would be dependent upon the duration and nature of activity in each phase, the time of day during which activity occurs, and the proximity of sensitive receptors. The noise produced by the venting of geothermal steam at the well head during well testing, and occasionally during production and facility operation, sounds similar to that produced by a jet engine. Unmuffled steam venting is unique to geothermal resource development and has the greatest potential for producing significant noise impacts, averaging 100 decibels (dB) at $15 \mathrm{~m}(50 \mathrm{ft})$ and $90 \mathrm{~dB}$ at $75 \mathrm{~m}(250 \mathrm{ft})$ (DOI 1973).

Predictions of total noise levels (including background) resulting from activities of DOE's hydrothermal, geopressure, hot dry rock, and exploratory well drilling 
projects ranged from negligible to about $100 \mathrm{~dB}$. In most cases, noise levels and impact predictions were based on extrapolations from known data for noiseproducing equipment and activities. For example, modeling was performed to estimate impacts of drilling at the Pleasant Bayou geopressure well [14]. The information obtained from this study was subsequently applied to impact predictions for other geopressure projects.

Noise impacts for most $D O E$ projects were predicted to be minimal and insignificant. Mitigation measures were recommended for projects where sensitive receptors were identified and/or local or federal noise standards could be exceeded, such as at the Rorabaugh Loan Guaranty project site in Sonoma County [34] and the South Brawley project site in Imperial County, California [26].

The only potentially significant noise impact predicted for all projects was expected to result from accidental unmuffled well venting, as in the case of a well blowout.

\subsubsection{Groundwater, Geology, and Soils}

\subsubsection{Generic impacts}

\section{Groundwater}

In its hydrothermal, geopressure, and hot dry rock programmatic environmental assessments $[2,10,13]$ DOE noted that contamination of freshwater aquifers could occur during geothermal well drilling and testing, during production and facility operation, and from accidents. If a freshwater aquifer lies above a geothermal reservoir, improperly conducted drilling, withdrawal, and injection could introduce contaminants to the aquifer. This contamination would occur if improperly cemented well casings allowed access to groundwater. The cements, pipes, and casings used in well drilling are highly susceptible to deterioration in the hightemperature, corrosive environment of geothermal brines. Similar contamination could also occur from drilling of oil and other nongeothermal wells, but the contaminants introduced would differ. Brine pits and other liquid waste storage pits and ponds are another potential source of groundwater contamination. If not lined with an impervious material, they could generate leachate uniquely characterized by the high dissolved solids concentrations of geothermal brines and/or toxic constituents from drilling muds (e.g., barium), lubricants, or other materials stored in the pits or present in the brine itself. Such leachate could contaminate shallow groundwater aquifers, recharge areas, and soils. Because geothermal brine is not produced in hot dry rock projects, groundwater impacts are more likely to result from infiltration due to surface spills and storage of drilling and/or other wastes in improperly lined pits.

In addition to thermal and chemical groundwater contamination, the hydrothermal subprogrammatic environmental assessment [2] pointed out that the availability of groundwater in some project areas could be affected if interactions between the geothermal reservoir and shallower groundwater aquifers lower the level in the water-supply aquifer. Groundwater resources may also be depleted if 
they are used to supply makeup water for conventional, wet, cooling towers. In cases where additional water is required to recharge a geothermal reservoir, groundwater supplies could be depleted, particularly in arid western regions where groundwater is appropriated and demand already exceeds recharge rates.

Accidents also present a potential threat to groundwater quality. A casing failure, a subsurface blowout, or a major spill could contaminate the soil and shallow groundwater with geothermal brine, rendering it unsuitable for potable or other uses. The extent of contamination would depend on the volume and quality of geothermal fluid that enters freshwater aquifers and the duration of the accident. Blowouts are more likely to occur in geopressured geothermal drilling because of the nature of the resource.

\section{Geology and soils}

Geothermal exploration, development, and utilization involves the disturbance of both surface and underlying geological features. In fact, the existence and nature of the geothermal resource itself is the result of unique geological conditions in a particular area. Well drilling and testing, geophysical surveys, construction, and production of geothermal fluids during resource applications could result in environmental impacts due to erosion, induced subsidence, and induced seismicity. Depletion of the geothermal resource is also an impact of geothermal energy development.

Though not unique to geothermal resource development, erosion and landslides are potential problems, especially in areas of high relief. Landslides promote casing failure as well, endangering groundwater resources. In particularly arid regions, wind-induced erosion has been predicted to be additive to that which is waterinduced.

Subsidence may be induced by the withdrawal of geothermal fluids (which removes the fluid foundation of the overlying rock), if withdrawal exceeds recharge. Because of the large amount of fluids removed for geothermal applications, the potential for induced subsidence is an important consideration during impact assessment. Generic documents prepared by the DOE for its hydrothermal and geopressure programs $[2,13]$ described the potential for induced subsidence based on data regarding geological features and the nature of the geothermal resource in each development region. Hot-water-dominated geothermal reservoirs, such as those of the Imperial Valley in California, are believed to be most susceptible to induced subsidence, though data necessary to affirm this prediction are still being tabulated. Impacts of induced subsidence in the Imperial Valley would be more serious than in other geothermal development areas because of the sensitivity of agricultural activities, particularly irrigation, to changes in topography. Impacts of subsidence in geopressured zones could include the conversion of low-lying farmland to marsh and an upset of the ecological balance of existing wetlands. Because hot dry rock reservoir development involves no removal of subsurface fluids, the risk of induced subsidence is minimal.

Induced seismicity (and danger of triggering earthquakes) was predicted as a possible occurrence at some geothermal development locations, especially regions 
with preexisting fractures and zones of weakness and those of general seismic instability. Reinjection of geothermal fluids for reservoir-pressure maintenance (and prevention of induced subsidence) was reported as the most likely cause of induced seismicity, but only if very large volumes of fluid are injected under relatively high pressures into active fault systems. Such conditions may also occur during injection of fluid into hot dry rock reservoirs. Accurate records of injection rates, pressures, times, etc., are necessary to allay public concerns regarding the relationship of injection and naturally occurring seismicity. Although induced subsidence and induced seismicity can result from nongeothermal drilling and extraction, the volume of fluid involved in geothermal activities may increase the potential for significant effects.

\subsubsection{Site-specific impacts}

The following discussion focuses on noteworthy site-specific impacts reported in Table 3.2.

\section{Groundwater}

Impacts to groundwater quality due to DOE's geothermal resource development and utilization projects were foreseen as minor and insignificant except in the case of accidents. Quantitatively, the availability of groundwater for consumptive use in geothermal operations was mentioned as a concern in arid western locales where water rights and appropriation are important issues. For the Raft River Geothermal Test Loop and Pilot Plant in Cassia County, Idaho $[3,6]$, concern was expressed regarding possible lowering of the water tables during well testing because of connections between the shallow freshwater aquifers and the geothermal reservoir. Reduction of productivity from nearby wells was predicted to be a consequence and a potentially significant impact. Similar concerns were raised for the CU-1 Venture Loan Guaranty project at Beryl and Lund, Utah [27], and the Fenton Hill Hot Dry Rock Project Expansion and Operation in Sandoval County, New Mexico [11], where groundwater is also scarce.

For the Hawaii Geothermal Well Flow Test [1] the possibility of saltwater encroachment was considered. Encroachment can occur if saltwater exists underneath or adjacent to fresh water and if there is a general lowering of the water table resulting from withdrawal of geothermal fluid. In addition, the salinity of production water could rise due to saltwater encroachment, creating a potential for shallow groundwater contamination through unlined sumps.

For all projects, mitigation measures (Sect. 3.2) were recommended to offset potential degradation of groundwater quality, and alternate sources of makeup water were suggested to eliminate the need for consumptive use of groundwater in locations having low recharge rates. 
Table 3.2. Summary of geological impacts predicted for DOE geothermal projects

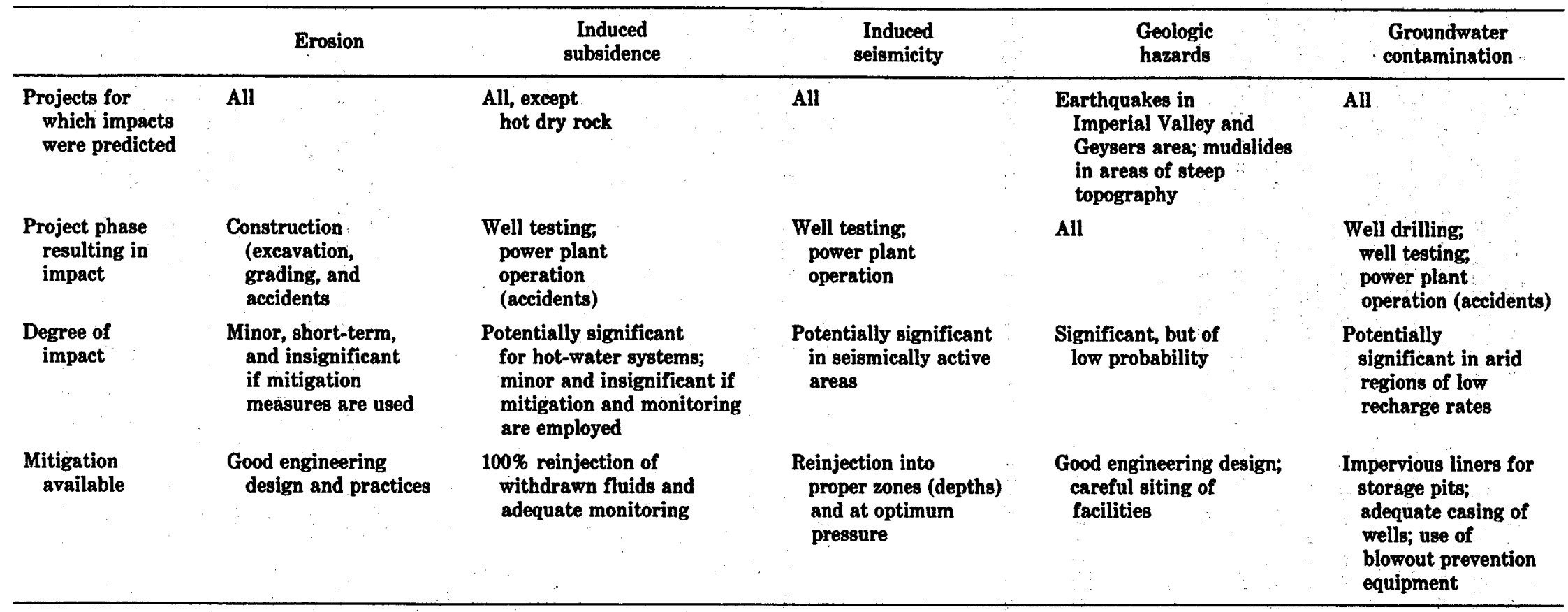




\section{Geology and soils}

Predictions of gradual reservoir depletion were made for those DOE projects involving substantial withdrawal of geothermal fluids, such as the Heber [9] and Baca [7] 50-MWe demonstration projects. An important consequence of such depletion is its effect on surface manifestations of geothermal activity such as hot springs or fumaroles. For the Baca project, hot springs in the Jemez Springs area and the Indian Springs on the Jemez Pueblo were predicted to be affected by flow depletion as a result of geothermal reservoir production. The possible impact of geothermal development at Coso Hot Springs in California's Mojave Desert [4] was also considered. In both cases, alteration of geothermal surface expressions could negatively impact cultural resources of native Americans, who use these phenomena in their religious practices and customs. Recreational uses or aesthetic qualities of geysers and other geothermal attractions at national or state parks might also be affected by reservoir depletion (Sect. 3.1.6).

Induced subsidence resulting from less than $100 \%$ reinjection of withdrawn geothermal fluids was predicted, especially in hot-water-dominated systems. DOE noted this potential in environmental assessments of the Baca and Heber demonstration projects, the South Brawley [26] and Roosevelt Hot Springs [29] geothermal (loan guaranty) projects, and the geopressure well drilling and testing projects in Texas and Louisiana. The common practice of reinjection into overlying aquifers will not, however, prevent subsidence induced by reservoir depletion. Baseline, operational, and postoperational monitoring were recommended in all cases to ensure that any induced subsidence would be detected before significant impacts resulted. (Sect. 3.2.3)

Erosion was seen as generally an unavoidable consequence of geothermal development and utilization activities, even direct heat applications and exploration activities. In most cases, it was concluded that, with appropriate mitigation, impacts would be minor. Erosion and subsequent siltation at the Baca site were considered as potentially significant because of effects on the water quality and biotic communities of the Jemez River (Sect. 3.1.4).

The likelihood of induced seismicity at DOE's geothermal project sites was predicted to be slight, though most of the projects are, or will be, located in seismically active regions. No specific predictions of induced seismicity were made for any project, because data on which to base such predictions are lacking. Use of careful reinjection techniques employed at low pressures and optimum intervals was recommended to minimize the potential for induced seismicity.

Accidents, especially a geothermal well blowout, were predicted to result in an uncontrolled flow of significant amounts of hot geothermal brine that could increase erosion, produce surface cratering, and damage the target reservoir locally.

\subsubsection{Surface Waters and Aquatic Ecology}

Discussion of impacts on surface waters and aquatic ecosystems is more thorough than for other subject areas because (1) more is known about many 
effects, (2) impacts often arise secondarily from other effects (e.g., subsidence or erosion), and (3) impacts are potentially more serious in many cases. In addition, there are enough important differences among the three major types of geothermal resources, and gross differences among their respective surface waters and aquatic communities, to warrant separate treatment of the three major groups of projects. Separate consideration is given, therefore, to projects in geopressured, hydrothermal, and hot dry rock formations. For those impacts common to all three, the discussion will be presented in the subsection on geopressured projects to avoid repetition in later subsections. Reference will then be made in later subsections to discussions on impacts in the geopressured subsection, as appropriate.

\subsubsection{Generic impacts}

\section{Geopressured projects}

These projects are, or would be, sited along the coastal regions of Louisiana and Texas $[13,15,22]$. Projects in this region appear to have the greatest potential for causing significant and possibly widespread impacts on surface water for reasons discussed below.

The EAs noted several potential effects of construction activities of geopressure projects (e.g., site clearing and leveling, canal dredging, and construction of spoil banks, production wells, disposal wells, storage ponds, and flood walls). Direct destruction of aquatic habitat would be limited to the immediate areas required for construction of drill-pads (0.4-0.8 ha), reserve ponds for drilling wastes (0.04 ha), and access roads or canals to the project sites. Because of the distances often involved, the most important causes of direct loss of habitat are likely to be construction and dredging activities usually associated with access roads or canals to the well sites. Storm- and tide-induced runoff from construction and drilling areas may contain lubricants and other potentially toxic substances from vehicles, equipment, and drilling mud. Water requirements for construction and drilling will not be significant. Sources of supply probably would be surface waters from nearby marshes or bayous in wetlands or from groundwater in upland areas. The use of surface waters could cause some loss of aquatic organisms in the immediate area of an intake through entrainment and impingement.

The EAs noted that dredging can have numerous indirect ecological effects, reviewed in detail by Morton (1977). In general, levels of total suspended solids (TSS) do not exceed natural levels (20 to $200 \mathrm{ppm}$ ) beyond a distance of $32 \mathrm{~m}$ (105 ft) from the dredge (Macklin 1962). In the shallow marsh and estuarine systems of the Frio areas, natural TSS may be as high as $500 \mathrm{ppm}$ [22]. Consequently, the ecological effects of increased turbidity and siltation resulting from dredging and other construction activities should usually be limited to the vicinity of the cause of disturbance. This area could be sizeable in projects involving road or canal construction.

Indirect adverse effects of dredging and other construction activities on aquatic organisms (especially in canals, channels, and marsh areas along the coast) were 
predicted in the EAs and are summarized below. Dredging remobilizes sediments that in some areas contain fairly high concentrations of pesticides, herbicides, heavy metals, and other toxic materials. These materials may enter and concentrate in aquatic food chains or affect organisms directly. Increased suspended solids and siltation may also

- reduce light penetration into the water column and thus limit photosynthesis and obscure vision of fishes;

- bury bottom-dwelling plants and animals or clog or irritate the feeding apparatus of filter feeders;

- abrade gills of fish, increasing susceptibility to disease and toxicants; and

- kill fish at extremely high concentrations.

The EAs further noted that silt can

- smother eggs, larval fish, and benthic food organisms;

- reduce available substrates for periphyton and rooted plants;

- destroy spawning beds by covering gravel bottoms;

- fill pools, lakes, and wetlands, resulting in the loss of aquatic habitat; and

- interfere with human use of water by reducing the aesthetic quality of natural water bodies and by diminishing water quality for domestic and industrial use.

Another potential effect of construction noted in the EAs is alteration of drainage and circulation patterns and flow rates in the vicinity of the test well. This effect could be particularly important in the coastal Frio areas of Louisiana where dredge and fill operations have already permitted intrusions of saline water into previously brackish or freshwater areas. The adverse ecological effects of these saline intrusions, and the effects of circulation changes induced by canals, spoil banks, and levees, are potentially severe, ranging from subtle shifts in species composition to lowered productivity and then to complete destruction of coastal wetlands (Newchurch et al. 1978).

Once drilling begins, drilling muds, hydraulic fluid, lubricants, and other chemicals (containing potentially toxic substances) associated with the wellhead and other facilities could contaminate nearby aquatic ecosystems through leakage, spills, or floods. Sensitive flora and fauna could be killed, while less sensitive organisms may suffer decreased growth and/or reproduction.

Land subsidence and accidental, uncontrolled releases of geopressured fluids constitute the principal hazards to surface waters and their aquatic communities during flow testing and operation of production and disposal wells. The EAs considered subsidence to be unlikely. However, if subsidence did occur, significant alterations of flow regimes in wetlands and streams in the coastal zone could result. Subsidence-induced alterations of flow regimes along the coast could impose substantial adverse effects on stream and wetland communities. Aquatic communities of upland waters are far less likely to be affected by subsidence. 
The impact of an accidental release of geopressured fluids would be determined by the brine's flow rate, total volume, temperature, salinity, and chemical composition, as well as the physicochemical and biological characteristics of the receiving surface waters. All of these parameters may vary greatly from site to site. Although it is difficult to predict the flow rate of a major blowout accurately, a maximum rate of about $6400 \mathrm{~m}^{3} / \mathrm{d}(40,000 \mathrm{bbl} / \mathrm{d})$ was assumed in the EAs for assessment purposes. At this flow rate, a typical ring dike would be able to contain the brine for $3 \mathrm{~d}$. Thereafter, the hot brine would enter existing drainage systems until the blowout exhausted itself or a relief well were drilled, a procedure that could take several weeks. Because of its greater density with respect to freshwater, the brine can be expected to sink to the bottom of waterways, where mixing and dilution may be slowed until the brine finally meets open bay waters.

Hot brines from blowouts and spills can have adverse ecological effects in both freshwater and estuarine systems. Potential impacts noted in the EAs include:

- thermal stress and impairment of osmoregulatory functions, resulting in decreased growth or death, particularly of freshwater organisms and young fish and shellfish;

- toxic effects of ammonia, hydrogen sulfide, boron, and trace metals (especially copper, zinc, lead, magnesium, and manganese); and

- accumulations of toxic substances in sediments and in the food chain.

Many of the constituents listed above have been shown to occur in brines at concentrations potentially harmful to aquatic plants and animals, as evidenced by baseline data presented in the subprogrammatic environmental assessment for drilling and testing in the Frio, Wilcox, and Tuscaloosa formations [22]. Temperature and $\mathrm{pH}$ of the aquatic system largely dictate how ammonia, hydrogen sulfide, and trace elements will speciate and behave in the aquatic system. Ammonia, for example, is more toxic at high $\mathrm{pH}$ than at low $\mathrm{pH}$, while the opposite is true for hydrogen sulfide. Detailed reviews and discussions of geopressured brines and their physics, chemistry, and toxicity can be found in Gustavson et al. (1977), Kharaka et al. (1979), DOE (1978), and Cushman et al. (1980).

Hydrologic characteristics of the aquatic ecosystem receiving geopressured effluents would also have a large effect on the magnitude of the ecological impact sustained by that system. Systems with rapid and efficient mixing and dilution would dissipate and dilute the geopressured fluids rapidly, therefore minimizing biological effects.

\section{Hydrothermal projects}

The environmental impact assessment for the hydrothermal subprogram [2] examined the generic impacts on aquatic resources resulting from the development of hydrothermal resources in the western United States and Hawaii. The nature and intensity of impacts may vary widely among the specific projects (addressed in Sect. 3.1.4.2) in response to the variability of physical, chemical, and biological factors at 
their respective sites. With the exception of the two projects sited at the Geysers, however, all of the hydrothermal projects surveyed in this study share an arid to semiarid climate and a scarcity of fresh surface water.

Two major sources of impacts were predicted to result from development of hydrothermal resources:

- construction-induced erosion followed by increased turbidity and siltation, and

- the release of liquid effluents.

Chemical and thermal contamination of area surface waters may occur from leaks or spills from holding ponds and mudpits and, most importantly, from deliberate or accidental releases of geothermal fluids (e.g., blowout) and cooling blowdown. Heat and toxic substances in spilled or leaked fluids may harm or destroy the flora and fauna of receiving waters (e.g., fish spawning grounds in the Cascades and Geysers hydrothermal resource regions). Geothermal fluids that are sufficiently clean and cool could be beneficial to local water resources.

In the event that surface water is used to satisfy project demands, less water will be available for other users, including aquatic biota and wildlife. This loss could be important if the water is diverted from small streams or arid areas. Further, diversions of surface water may result in impingement or entrainment of fish and other aquatic organisms.

\section{Hot dry rock projects}

The hot dry rock subprogram EA [10] evaluated the potential effects of geothermal development on surface waters and aquatic ecology in the 11 hot dry rock resource regions. All of these regions lie in the western United States, Hawaii, or Alaska, and many are arid to semiarid. The expected impacts of development are generally the same as those identified for development of hydrothermal resources. Harm or death to resident fish and aquatic invertebrates, depending on the severity of the stress imposed, could result from

- construction-induced erosion followed by increased turbidity and siltation in streams (the Cascades, Aleutian Islands, Yellowstone, Continental Divide, and Hawaii regions are rated most susceptible in this respect);

- possible contamination of waterways from chemical spills and leaking or failure of mudpits and settling of evaporation ponds;

- improper disposal of potentially toxic cooling system blowdown; and

- accidental or uncontrolled releases of geothermal or circulating liquids.

Other important potential impacts common to both hot dry rock and hydrothermal development include increased demands on limited surface or groundwater resources, particularly in the Southern Basin and Range region (up to $45 \mathrm{~m}^{3} / \mathrm{d}$ during drilling) and increased pressures on local fisheries and their habitat as a result of the increased industrialization likely to follow resource development. 
Direct heat applications (e.g., heating of buildings) have special implications for aquatic ecosystems because such uses could require transport of hot fluid via pipelines over significant distances, possibly requiring stream crossings and, in general, involving short-term disturbances of substrate, water quality, and downstream biota. In addition, longer transport distances increase the probability of leaks.

Because hot dry rock operations normally do not penetrate formations containing pressurized fluids, the probability and severity of a blowout or other uncontrolled release of fluids is considerably lower than that associated with most hydrothermal or geopressured formations. Although an accidental release of circulating water from the rock would exert some degree of thermal stress on any receiving aquatic ecosystem, it would not likely be very toxic because of the low contact time with the rock. Recirculation of the water, on the other hand, would increase contact time, thereby permitting the buildup of concentrations of leached substances to possibly toxic levels. Finally, with the exception of an accidental penetration of a hydrothermal resource which could result in a blowout and the associated adverse effects on surface waters and their biota described earlier for hydrothermal and geopressure programs, any releases of fluids are expected to be small and readily controlled.

\subsubsection{Site-specific impacts}

Most of the impacts predicted for site-specific projects were identified in the discussion of impacts generic to geothermal exploitation (Sect. 3.1.4.1). Important impacts predicted and/or unique to a particular project are addressed in this section.

Tables 3.3 and 3.4 summarize the principal adverse effects on aquatic resources at each of 26 projects on the basis of their respective EAs. The first table shows those impacts (predicted or implied) on aquatic resources which may occur as a result of construction and operation of the projects, excluding major accidents. The second table shows only those impacts related to major accidents such as blowouts. In this discussion, flooding and subsidence-induced alteration of drainage patterns or flow regimes are considered to be major accidents.

For each project listed in Table 3.3, up to four letter symbols are listed under a given column (i.e., impact) heading: " 0 " for zero or virtually zero, " $L$ " for low, " $M$ " for moderate, and " $\mathrm{H}$ " for high. With the exception of the column labeled "Aquatic Resource Value," the four positions under a column represent the following, from left to right, respectively: (1) the relative probability that the impact will occur; (2) the length of time the impact would last; (3) the severity of the impact on aquatic resources locally; and (4) the severity of the impact area-wide. For example, construction and operation of the Pleasant Bayou geopressured project $(\mathrm{H} / \mathrm{M} / \mathrm{M} / \mathrm{L})$ would involve, over a moderate length of time, a high probability of 
Tublo 3.3. Predieted and implied impacts on surface aquatic resources (excluding major accidents)

\begin{tabular}{|c|c|c|c|c|c|c|c|c|c|}
\hline $\begin{array}{l}\alpha \\
\cdots\end{array}$ & $\begin{array}{c}\begin{array}{c}\text { Aquatic } \\
\text { resource } \\
\text { value }\end{array} \\
\text { Local/area }\end{array}$ & $\begin{array}{c}\text { Water } \\
\text { use } \\
{\left[\mathbb{R}^{2} / \mathbb{I}^{d}\right.}\end{array}$ & $\begin{array}{l}\text { Water } \\
\text { quality }\end{array}$ & $\begin{array}{c}\begin{array}{c}\text { Turbidity } \\
\text { and } \\
\text { sedimentation }\end{array} \\
\mathrm{P} / \mathrm{T} / \mathrm{T} / \mathrm{A}\end{array}$ & $\begin{array}{l}\text { Inereased } \\
\text { salinity }\end{array}$ & $\begin{array}{c}\begin{array}{c}\text { Direet } \\
\text { habitat } \\
\text { destruetion }\end{array} \\
\text { P/T/VA }\end{array}$ & $\begin{array}{c}\text { Altered } \\
\text { aquatic } \\
\text { communities }\end{array}$ & $\begin{array}{l}T / \mathrm{B}^{6} \\
\text { species }\end{array}$ & $\begin{array}{l}\text { Altered } \\
\text { circulation } \\
\text { or flow } \\
\mathrm{P} / \mathrm{T} / \mathrm{A}\end{array}$ \\
\hline & & & & & & & & & \\
\hline & & & & Geopressured & & & & & \\
\hline $\begin{array}{l}\text { Pleasant Bayou } \\
\text { Sweet Lake } \\
\text { Gladys McCall } \\
\text { Dow Parcperdie } \\
\text { LaFourche Crossing } \\
\text { Southeast Pecan Island } \\
\text { Blessing Prospect }\end{array}$ & $\begin{array}{l}\mathbf{H} / \mathbf{H} \\
\mathbf{H} / \mathbf{H} \\
\mathbf{H} / \mathbf{H} \\
\mathbf{L} / \mathbf{H} \\
\mathbf{H} / \mathbf{H} \\
\mathbf{H} / \mathbf{H} \\
\mathbf{L} \mathbf{M} / \mathbf{H}\end{array}$ & $\begin{array}{l}?^{h} / ? / \mathrm{L} / 0 \\
\mathrm{M} / \mathrm{M} / ? / ? \\
\mathrm{M} / \mathrm{M} / \mathrm{M} / \mathrm{L} \\
0 \\
? / ? / \mathrm{L} \\
? / ? / \mathrm{L} / 0 \\
0\end{array}$ & $\begin{array}{l}H / M / M / L \\
H / M / M / L \\
M / M / M / L \\
H / L / M / L \\
0 \\
H / M / M / L \\
M / M / M / L\end{array}$ & $\begin{array}{l}\mathrm{H} / \mathrm{L} / \mathrm{L} / 0 \\
\mathrm{H} / \mathrm{L} / \mathrm{M} / 0 \\
\mathrm{H} / \mathrm{L} / \mathrm{M} / 0 \\
\mathrm{H} / \mathrm{L} / \mathrm{M} / \mathrm{L} \\
\mathrm{H} / \mathrm{M} / \mathrm{M} / \mathrm{L} \\
\mathrm{H} / \mathrm{L} / \mathrm{M} / \mathrm{L} \\
\mathrm{M} / \mathrm{L} / \mathrm{L} / 0\end{array}$ & $\begin{array}{l}0 \\
0 \\
0 \\
0 \\
\mathrm{H} / \mathrm{L} / \mathrm{M} / \mathrm{L} \\
\mathrm{M} / \mathrm{H} / \mathrm{T} / ? \\
0\end{array}$ & $\begin{array}{l}0 \\
\mathrm{H} / \mathrm{H} / \mathrm{M} / \mathrm{L} \\
\mathrm{H} / \mathrm{H} / \mathrm{M} / \mathrm{L} \\
\mathrm{H} / \mathrm{H} / \mathrm{M} / 0 \\
0 \\
\mathrm{M}^{2} / \mathrm{H} / \mathrm{H} / \mathrm{M} \\
0\end{array}$ & $\begin{array}{l}\mathrm{H} / \mathrm{M} / \mathrm{M} / \mathrm{L} \\
\mathrm{H} / \mathrm{H} / \mathrm{H} / \mathrm{L} \\
\mathrm{H} / \mathrm{H} / \mathrm{M} / \mathrm{L} \\
\mathrm{H} / \mathrm{L} / \mathrm{H} / \mathrm{L} \\
\mathrm{H} / \mathrm{H} / \mathrm{M} / \mathrm{L} \\
\mathrm{M} / \mathrm{H} / \mathrm{H} / \mathrm{M} \\
\mathrm{L} / \mathrm{M} / \mathrm{M} / \mathrm{L}\end{array}$ & $\begin{array}{l}L / M / ? / ? \\
M / M / 9 / ? \\
M / M / M / L \\
L / L / L / 0 \\
H / M / H / L \\
M / M / M / L \\
0\end{array}$ & $\begin{array}{l}\mathrm{L} / \mathrm{H} / ? / ? \\
\mathrm{H}^{0} / \mathrm{H} / ? / ? \\
\mathrm{M} / \mathrm{H} / \mathrm{M} / \mathrm{L} \\
\mathrm{H} / \mathrm{H} / \mathrm{L} / 0 \\
\mathrm{M} / \mathrm{M} / \mathrm{M} / \mathrm{L} \\
\mathrm{M} / \mathrm{H} / ? / ? \\
0\end{array}$ \\
\hline - $\quad 4$ & & & & Hydrothermal & & & & & \\
\hline $\begin{array}{l}\text { Hawaii Flow Teat } \\
\text { Hawaii Research Station } \\
\text { Raft River Test Loop } \\
\text { Raft River Pilot Plant } \\
\text { Coso Well Test } \\
\text { Baca Ranch Demonstration } \\
\text { Marlin Direet Heat } \\
\text { Heber Demonstration } \\
\text { Brady Hot Springs } \\
\text { South Brawley } \\
\text { Beryl and Land } \\
\text { Roosevelt Hot Springs } \\
\text { NCPA No. } 2 \\
\text { Westmorland Development } \\
\text { Oregon Trail Mushrooms } \\
\text { Rorabavgh Lease } \\
\text { Republic East Mesa } \\
\text { Boise Distriet Heating }\end{array}$ & $\begin{array}{l}f / f \\
f / f \\
L-M / L-M \\
L-M / L-M \\
L-M / f \\
H / H \\
f / M \\
L-M / M-H \\
f / f \\
L-M / M-H \\
f / f \\
f / f \\
\text { H/H } \\
\mathbf{L}-M / M-H \\
\text { L-M/L-M } \\
\text { H/H } \\
\text { L-M/M-H } \\
M-H / M-H\end{array}$ & $\begin{array}{l}0 \\
0 \\
0 \\
0 \\
0 \\
0 \\
M / L / 0 / 0 \\
H / H / L / L \\
0 \\
H / H / L / L \\
0 \\
0 \\
H / L / L / L \\
H / M / L / L \\
0 \\
0 \\
0 \\
0\end{array}$ & 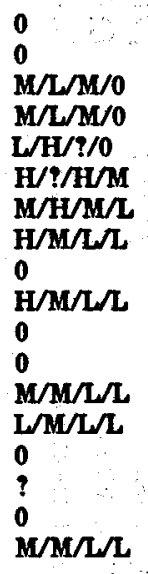 & $\begin{array}{l}0 \\
0 \\
\mathrm{H} / \mathrm{L} / \mathrm{M} / \mathrm{q} \\
\mathrm{H} / \mathrm{L} / \mathrm{M} / \\
0 \\
\mathrm{H} / \mathrm{M} / \mathrm{H} / \mathrm{M} \\
\mathrm{M} / \mathrm{L} / \mathrm{M} / \mathrm{L} \\
! \\
0 \\
? \\
0 \\
\mathrm{~L} / \mathrm{L} / \mathrm{L} / 0 \\
\mathrm{M} / \mathrm{M} / \mathrm{L} / \mathrm{L} \\
? \\
? \\
\mathrm{H} / \mathrm{M} / \mathrm{M} / \mathrm{M} \\
0 \\
? \mathrm{~L} / \mathrm{L} / \mathrm{L} / \mathrm{O}\end{array}$ & $\begin{array}{l}0 \\
0 \\
0 \\
0 \\
? \\
0 \\
\mathbf{M} / \mathbf{H} / \mathbf{L} / \mathbf{L} \\
\mathbf{H} / \mathbf{H} / \mathbf{L} / \mathbf{L} \\
0 \\
\mathbf{H} / \mathbf{H} / \mathbf{L} / \mathbf{M} \\
0 \\
0 \\
0 \\
\mathbf{L} / \mathbf{H} / \mathbf{M} / \mathbf{M} \\
0 \\
0 \\
0 \\
\mathbf{L} / \mathbf{H} / \mathbf{L} / 0\end{array}$ & $\begin{array}{l}0 \\
0 \\
\mathbf{H} / \mathbf{M} / \mathbf{H} / \mathbf{0} \\
\mathbf{H} / \mathbf{M} / \mathbf{H} / 0 \\
0 \\
0 \\
0 \\
0 \\
0 \\
0 \\
0 \\
0 \\
0 \\
0 \\
0 \\
\mathbf{M} / \mathbf{H} / \mathbf{M} / 0 \\
0 \\
\mathbf{L} / \mathbf{M} / \mathbf{L} / 0\end{array}$ & $\begin{array}{l}? / ? / 0 / ? \\
? / ? / 0 / ? \\
\mathrm{H} / \mathrm{M} / \mathrm{H} / \mathrm{L} \\
\mathrm{H} / \mathrm{M} / \mathrm{H} / \mathrm{L} \\
\mathrm{L} / \mathrm{H} / \mathrm{T} / \mathrm{0} \\
\mathrm{H} / ? / \mathrm{H} / \mathrm{M} \\
\mathrm{M} / \mathrm{H} / \mathrm{M} / \mathrm{L} \\
\mathrm{L} / \mathrm{H} / \mathrm{L} / \mathrm{L} \\
0 \\
\mathrm{~L} / \mathrm{H} / \mathrm{L} / \mathrm{M} \\
0 \\
0 \\
\mathrm{M} / \mathrm{M} / \mathrm{L} / \mathrm{L} \\
\mathrm{L} / \mathrm{H} / \mathrm{M} / \mathrm{M} \\
0 \\
\mathrm{M} / \mathrm{M} / \mathrm{H} / ? \\
0 \\
\mathrm{~L} / \mathrm{M} / \mathrm{L} / 0\end{array}$ & $\begin{array}{l}0 \\
0 \\
0 \\
0 \\
0 \\
0 \\
0 \\
0 \\
0 \\
0 \\
0 \\
0 \\
0 \\
0 \\
0 \\
0 \\
0 \\
0\end{array}$ & $\begin{array}{l}0 \\
0 \\
\mathrm{~L} / \mathrm{H} / ? / ? \\
\mathrm{~L} / \mathrm{H} / ? / ? \\
\mathrm{~L} / \mathrm{H} / ? / 0 \\
\mathrm{M} / \mathrm{M} / \mathrm{M} / \mathrm{L} \\
0 \\
\mathrm{M} / \mathrm{M} / \mathrm{M} / \mathrm{L} \\
0 \\
0 \\
0 \\
0 \\
0 \\
0 \\
0 \\
0 \\
0 \\
0\end{array}$ \\
\hline & & & & Hot dry rock & & & & & \\
\hline Fenton Hill & $f / f$ & 0 & 0 & $L / L / L / 0$ & 0 & 0 & 0 & 0 & 0 \\
\hline
\end{tabular}

aFederally designated threatened or endangered species.

${ }^{\circ} \mathbf{P}=$ probability of occurrence: 0 - zero; $\mathrm{L}=$ low; $\mathrm{M}=$ moderate; $\mathrm{H}=$ high.

oT - amount of time impact may last: $0=$ zero; $L=$ low; $M=$ moderate; $H=$ long-term.

$d I-$ local severity of impact: 0 - zero; $L=$ low; $M=$ moderate; $H=$ high.

- A - severity of impact over a wide area: 0 - zero; $L=$ low; $M=$ moderate; $H=$ high.

$f$ There is an absence of perennial surface waters.

If sited in wetlands or estuaries.

Insufficient information to evaluate impacts. 
Table 3.4. Potential accidents and their effects on aquatic resources

\begin{tabular}{|c|c|c|c|}
\hline & $\begin{array}{c}\text { Blowouts } \\
\text { or major } \\
\text { spills } \\
\left(P^{a} / I^{b} / A^{c}\right)\end{array}$ & $\begin{array}{l}\text { Flooding } \\
\text { (P/I/A) }\end{array}$ & $\begin{array}{c}\text { Altered } \\
\text { circulation } \\
\text { (subsidence) } \\
(\mathrm{P} / \mathrm{I} / \mathrm{A})\end{array}$ \\
\hline$\therefore$ & Geopressured & & \\
\hline $\begin{array}{l}\text { Pleasant Bayou } \\
\text { Sweet Lake } \\
\text { Gladys McCall } \\
\text { Dow Parcperdue } \\
\text { LaFourche Crossing } \\
\text { Southeast Pecan Island } \\
\text { Blessing Prospect }\end{array}$ & $\begin{array}{l}\mathrm{M} / \mathrm{H} / \mathrm{H} \\
\mathrm{M} / \mathrm{H} / \mathrm{M} \\
\mathrm{M} / \mathrm{H} / \mathrm{M} \\
\mathrm{M} / \mathrm{H} / \mathrm{M} \\
\mathrm{M} / \mathrm{H} / \mathrm{M} \\
\mathrm{M} / \mathrm{H} / \mathrm{M} \\
\mathrm{L} / ?^{d} / ?\end{array}$ & $\begin{array}{l}\mathrm{M} / \mathrm{M} / ? \\
\mathrm{~L} / \mathrm{M} / ? \\
\mathrm{H} / ? / ? \\
\mathrm{~L} / \mathrm{M} / \mathrm{L} \\
\mathrm{H} / \mathrm{M} / \mathrm{M} \\
\mathrm{H} / \mathrm{H} / \mathrm{M} \\
\mathrm{L} / \mathrm{M} / \mathrm{L}\end{array}$ & $\begin{array}{l}0 \\
\mathrm{~L} / ? / ? \\
0 \\
\mathrm{M} / \mathrm{L} / 0 \\
\mathrm{~L} / ? / ? \\
\mathrm{~L} / ? / ? \\
\mathrm{M} / ? / \mathrm{L}\end{array}$ \\
\hline & Hydrothermal & & \\
\hline $\begin{array}{l}\text { Hawaii Flow Test } \\
\text { Hawaii Research Station } \\
\text { Raft River Test Loop } \\
\text { Raft River Pilot Plant } \\
\text { Coso Well Test } \\
\text { Baca Ranch Demonstration } \\
\text { Marlin Direct Heat } \\
\text { Heber Demonstration } \\
\text { Brady Hot Springs } \\
\text { South Brawley } \\
\text { Beryl and Lund } \\
\text { Roosevelt Hot Springs } \\
\text { NCPA No. 2 } \\
\text { Westmorland Development } \\
\text { Oregon Trail Mushrooms } \\
\text { Rorabaugh Lease } \\
\text { Republic East Mesa } \\
\text { Boise District Heating }\end{array}$ & $\begin{array}{l}\mathrm{L} / 0 / 0 \\
\mathrm{~L} / 0 / 0 \\
\mathrm{~L} / \mathrm{H} / \mathrm{L} \\
\mathrm{L} / \mathrm{H} / \mathrm{L} \\
\mathrm{L} / \mathrm{M} / ? \\
? / \mathrm{H} / \mathrm{H} \\
\mathrm{L} / ? / ? \\
\mathrm{~L} ? / \mathrm{H} / \mathrm{L} \\
\mathrm{L} ? / 0 / 0 \\
\mathrm{~L} ? / \mathrm{H} / \mathrm{L} \\
\mathrm{L} ? / \mathrm{L} / 0 \\
\mathrm{~L} ? / 0 / 0 \\
\mathrm{~L} / \mathrm{H} / \mathrm{M} \\
\mathrm{M} / \mathrm{H} / \mathrm{M} \\
\mathrm{L} / \mathrm{L} / \mathrm{L} \\
? / \mathrm{H} / \mathrm{H} \\
\mathrm{L} / \mathrm{L} / \mathrm{L} \\
\mathrm{L} / \mathrm{L} / \mathrm{L}\end{array}$ & $\begin{array}{l}? / 0 / 0 \\
? / 0 / 0 \\
0 \\
0 \\
\mathrm{~L} ? / \mathrm{L} / 0 \\
? \\
\mathrm{~L} ? / ? / 0 \\
0 \\
\mathrm{~L} / \mathrm{L} / 0 \\
? \\
? \\
? \\
0 \\
\mathrm{~L} ? \\
0 \\
\mathrm{~L} / \mathrm{H} / \mathrm{M} \\
\mathrm{L} ? / \mathrm{L} / 0 \\
\mathrm{~L} ? / \mathrm{L} / 0\end{array}$ & $\begin{array}{l}0 \\
0 \\
\mathrm{M} / \mathrm{L} / 0 \\
\mathrm{M} / \mathrm{L} / 0 \\
\mathrm{~L} / \mathrm{M} / 0 \\
\mathrm{~L} ? \\
\mathrm{~L} / 0 / \mathrm{L} \\
\mathrm{L} / \mathrm{M} / 0 \\
0 \\
? / \mathrm{H} / ? \\
0 \\
0 \\
\mathrm{M} / \mathrm{L} / 0 \\
\mathrm{~L} / \mathrm{H} / ? \\
0 \\
\mathrm{~L} / \mathrm{M} / 0 \\
\mathrm{~L} / \mathrm{L} / 0 \\
\mathrm{~L} / \mathrm{L} / 0\end{array}$ \\
\hline \multicolumn{4}{|c|}{ Hot dry rock } \\
\hline Fenton Hill & $\mathbf{0}$ & $?$ & 0 \\
\hline
\end{tabular}

aProbability of occurrence: $0=$ zero; $L=$ low; $M=$ moderate; $\mathrm{H}=$ high.

${ }^{b}$ Severity of impacts on local aquatic resources: $0=$ zero; $L=$ low; $\mathbf{M}=$ moderate; $\mathbf{H}=$ high.

'Severity of impacts on area aquatic resources: $0=$ zero; $L=$ low; $M=$ moderate; $H=$ high.

Insufficient information to evaluate the potential for accidents and their effects.

alterations of moderate severity in aquatic communities locally but only low severity in the general area. Because the EAs often did not explicitly state the probability, severity, or length of time of a given impact, these values were often assigned on the basis of the staff's interpretation of all of the pertinent information and analyses presented in each document. Where the EA remained silent, or no reasonable assessment was considered possible on the basis of the available information, a question mark was entered.

It is evident from Table 3.3 that, in the absence of major accidents, most of the projects surveyed in this study were not expected to impose aquatic impacts of high 
or even moderate severity beyond the immediate or nearby environs. Possible exceptions to this generalization include Baca Ranch in New Mexico and Southeast Pecan Island in Louisiana (see discussion below).

The geopressured projects as a group, however, were predicted to have a much greater potential for imposing moderate-to-high-severity impacts on local aquatic resources of relatively high value. Four of the seven geopressured projects would or could be sited directly in wetland or estuarine waters resulting in direct destruction of potentially high quality aquatic habitat and its resident communities (see Sect. 3.1.4.1 for further discussion of the aquatic resources of the geopressured zone). In the case of the Dow Parcperdue project, drainage ditches providing a small amount of perennial aquatic habitat would have to be relocated. Additionally, six of the geopressured projects would lie in or near habitat of the American alligator, a species designated by the U.S. Department of the Interior as threatened in much of the geopressured zone. None of the hydrothermal or hot dry rock projects surveyed in this study, on the other hand, would be sited in or near habitat known to harbor threatened or endangered aquatic species.

In contrast to the geopressured projects, most of the hydrothermal projects and the hot dry rock project would be sited in arid or semiarid regions having aquatic resources of low to moderate quality and quantity or no perennial surface waters at all. In the latter category are five hydrothermal projects (the two Hawaii projects, Brady Hot Springs in Nevada, Beryl and Lund in Utah, and Roosevelt Hot Springs in Utah) and the Fenton Hill hot dry rock project. Four of the hydrothermal projects (Heber, East Mesa, South Brawley, and Westmorland) would be located in the arid Imperial Valley of southern California. The EAs for South Brawley and Westmorland both predicted on the basis of a study by Goldsmith (1976) that their projects would each contribute incrementally (a maximum of $240 \mathrm{mg} / \mathrm{L} / \mathrm{yr}$ ) to the salinization of the already saline Salton Sea $(38,000 \mathrm{mg} / \mathrm{L})$ as a result of cooling tower blowdown and consumption of irrigation return flow or other water that would normally enter the Salton Sea. The EAs further stated that "the additional water use would accelerate the approach to the critical salinity level for the survival of fish larvae." Apparently addressing the issue from the perspective of full-field development, the EAs also stated that without a regional salinity-control program, geothermal development could "jeopardize the value of the Salton Sea as a fishery, wildfowl, and hunting resource" [26, 30]. The Heber and East Mesa EAs, on the other hand, gave little attention to this issue other than to state that the cumulative increase in salinity and stress on fish populations attributable to each project would be minor if the mitigative measures described in Sect. 3.2.4 were implemented. The Westmorland EA also predicted increased competition for water between agriculture and geothermal development after completion of the Central Arizona Project.

At least four of the hydrothermal projects could reduce flows from nearby hot springs (Baca and Coso projects) or rivers (Baca and the two Raft River projects). Furthermore, the Baca, Rorabaugh, and NCPA No. 2 projects would be sited near perennial streams known for their high value as trout fisheries and for recreation. The probability of adverse effects on these streams and their biota from construction activities or blowouts (should they occur) was generally considered to be moderate to high. 
With regard to major accidents, projects located in the geopressured zone along the Gulf Coast posed the most serious potential hazards to aquatic resources. These resources, though often already disturbed by other activities of man, are of considerable value for their fisheries, wildlife, and waterfowl. As indicated in Table 3.4, possible reasons for these hazards include

- a greater probability of blowouts or pipeline failures due to the high pressures and temperatures encountered in geopressured-geothermal resources;

- a greater risk of oil pollution and oil fires or explosion should a blowout take place in an inadvertently tapped oil formation;

- the relatively higher probability of flooding of project facilities (four of the seven geopressured projects and especially the Gladys McCall project) which could be sited in estuaries or wetlands subject to tides and severe storms;

- the generally more serious consequences of subsidence in low relief estuaries and wetlands of complex hydrology and physicochemical dynamics such as those dominating the areas surrounding most of the geopressured projects; and

- the often extremely low quality of the production fluids (Sect. 3.1.4.1).

As shown by Table 3.4, the risk of blowouts is generally lower for hydrothermal projects. The probabilities of blowouts occurring at the Boise, Marlin, Hawaii, Raft River, Oregon Trail Mushrooms, and Fenton Hill projects would be particularly low because geothermal resource pressures are relatively shallow and low- to normallypressured or, in the case of Fenton Hill, consist merely of hot dry rock.

Subsidence could also cause serious impacts in the canal-laced terrain of low relief surrounding the hydrothermal projects of the Imperial Valley by altering the dominant flow regimes. Most of the EAs, however, considered the possibility of subsidence (sufficiently serious to alter flow regimes in irrigation canals) to be remote because reinjection of spent fluids would be practiced at most of these projects.

Some of the more likely and/or important aquatic impacts predicted for individual projects are described briefly below.

If a major blowout were to occur at the Dow Parcperdue project [20], severe degradation of water quality and destruction of resident aquatic biota of local drainage ditches due to salinity, heat, and contaminants was predicted. Although degradation would be less severe in Bayou Parcperdue and its associated marshes in terms of intensity, it would be more widespread and more important from an ecological perspective. Entry of the hot brine into the Vermilion River would be less disruptive to that ecosystem than to the bayou's.

Most of the impacts to aquatic systems discussed in Sect. 3.1.4.1 (generic impacts of geopressured development) were considered possible impacts of the Gladys McCall project [20], particularly because this site lies completely in coastal wetlands. The project would likely alter already disturbed flow regimes in the area (via road, levee, and pit construction). 
The EA for Pleasant Bayou [14] predicted major fish kills (and implied harm to the American alligator) in Chocolate Bayou and Chocolate Bay following large-scale accidental releases of geothermal fluids.

At La Fourche Crossing [17], possible changes in drainage patterns through construction activities or resulting channel sedimentation could alter vegetation composition and productivity, possibly in cypress-tupelo swamps.

The proposed test well at Southeast Pecan Island [18] could be located on a chenier (land ridge), in marshes, or offshore. Expected impacts were basically as described in preceding discussions for site-specific projects and in Sect. 3.4.1. However, if the project were sited offshore, temporary interference with commercial fishery operations and long-term damage to local fish and benthic invertebrate populations would be possible. This EA emphasized the adverse effects of construction of canals, predicting potentially severe impacts on aquatic resources if construction were to take place in previously undisturbed marsh or chenier areas. The EA also noted that the federally designated threatened American alligator occurs in the prime prospect area. According to the EA, a possible benefit of locating the project offshore could occur if fish are attracted to the well platform after the project is closed down.

Impacts of canal construction, maintenance, and spoil banks at Sweet Lake [19] were considered potentially severe and long lasting if the project were sited in wetlands (about one-third of the prime prospect area). In the event of a blowout, local flora and fauna within $300 \mathrm{~m}$ of the well would be harmed or killed by the high salinity of the fluid. Fish kills would be expected in adjacent and downstream aquatic systems. Contamination of irrigation water would be possible. A blowout during drilling through an oil or gas formation could result in potentially serious oil-related effects or fire damage.

By the time the EA for the Marlin, Texas, Direct Heat Project [8] had been written, the project had already caused lowered water quality in a small pond designed as a catchment basin by discharging to the pond via the city storm-water drainage system water contaminated with suspended solids, drilling mud, and mud additives. Any aquatic biota in the pond would probably be harmed by these effluents.

The EA for the Coso Well Testing Activity [4] predicted no impacts on surface waters and their biota from this project because no perennial, surface waters exist on or near the project, and fluids would be diverted to a reserve pit or an adjacent playa. Although not addressed in the EA, the playa's seasonal value to wildife and waterfowl could be compromised if spent fluids are discharged to it.

The EA for Geothermal Drilling Activity in the Coastal Plain and Piedmont Physiographic Provinces of the Eastern United States [12] considered potential impacts on aquatic resources to be generally similar in kind to those expected for western hydrothermal projects, but of even less consequence because of the small size of proposed operations and the relative abundance of water in the East. The rate of consumption of water would be so low that no significant competition with existing water uses is expected.

The Fenton Hill EA [11] addressed the only site-specific DOE hot dry rock project. Although hot water that has been circulated through the resource region 
would be released periodically down a dry arroyo, no adverse effects on surface waters or their aquatic communities were predicted because no permanent surface waters exist in the area. For the same reason, water requirements for the facility would be met with groundwater or water imported by truck. Exact water requirements could not be predicted, but supplying them could become a serious problem for the success of the operations.

\subsubsection{Land Use and Terrestrial Ecology}

This section describes impacts on land use and terrestrial ecology predicted to result from DOE geothermal projects. Because these effects were generally minor, straightforward, and similar for all projects, we dispense with separate consideration of generic- and site-specific effects in order to avoid repetition. Both programmatic and site- or area-specific impacts were reviewed, however, in preparing the analysis.

Predicted impacts for site- and area-specific projects are summarized in Table 3.5. With few exceptions, the type and severity of impacts were related to the scale of the project (e.g., well testing, pilot plant, or demonstration plant) and to the characteristics of the site, rather than to the specific geothermal technology employed. Impacts were generally qualitatively and quantitatively similar to construction impacts of like-sized energy production projects of other types, with few additional impacts resulting specifically from operation of a geothermal facility. In any case, impacts to land use and terrestrial ecology, when identified, were almost always considered to be minor.

With regard to land use, the low significance of impacts was primarily a result of the small areas affected and the generally compatible nature of surrounding existing uses. In most cases, such uses were for grazing or crop production. Many areas were of moderate or poorer quality for agriculture, as indicated by the small proportion of projects on which prime farmland was located (Table 3.5). In the remaining cases, projects were located in lands set aside for industrial or commercial development or already devoted to geothermal applications.

Impacts to terrestrial ecology, other than those due to cooling tower drift, were similarly minor because of the small land areas involved and the usually limited to moderate significance of the habitats affected. In a few cases, the presence of important habitat or endangered species in the area was identified, usually offsite, with an attendant potential for impacts (Table 3.6). Even in these cases, however, impacts were considered to be acceptable.

Projects involving power production were generally associated with the prospect of impacts from cooling tower drift (Table 3.5). Impacts were linked to effects on natural or agricultural vegetation by salt concentration, biocides, or other additives, or heavy metals or other chemicals from geothermal waters present in damaging levels in drift. There was always a high level of uncertainty about the concentrations of these materials in drift and their potential effects on the surroundings; hence, drift effects were often a subject of mitigation and monitoring recommendations (Sect. 3.2.5). 
Table 3.5. Major impacts predicted for site- and area-specific geothermal projects on land use and terrestrial ecology (excluding major accidents)

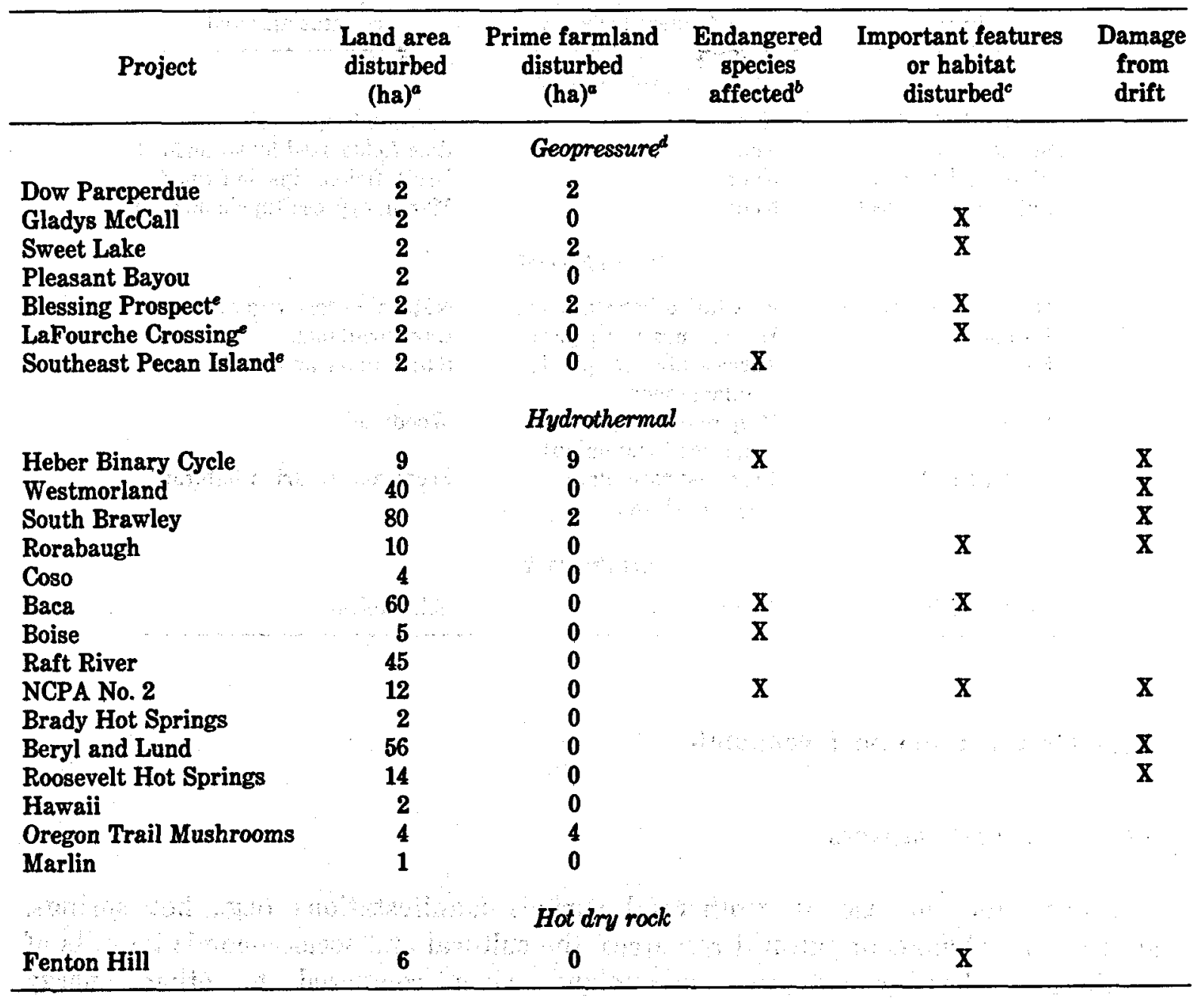

${ }^{\circ} 1$ ha $=2.471$ acres.

Includes listed or proposed, state and federal endangered, threatened, or rare plant and animal species which could be significantly affected.

Includes features such as springs, seeps, and dens or nesting areas and habitat such as important wintering grounds, highly productive wetlands, or important feeding areas (e.g., grain fields) which could be significantly affected.

${ }^{2}$ Area disturbed could be somewhat greater if lengthy new access roads were needed.

- Information refers to worst impacts for a single site within a larger prospect area.

Also uncertain, and not identified in Tables 3.5 and 3.6, were potential effects of accidents. Most documents identified the possibility of blowouts and other spills of geothermal fluids, but neither the probability of spills nor the nature and extent of effects could be accurately specified. The probability of a blowout was generally identified as low, and the areal extent of effects, if mentioned, was in the range of 1 to 5 ha. Again, prevention of blowouts and other spills was the subject of mitigation measures (Sect. 3.2.5) 
Table 3.6. Summary of important habitats and species potentially subject to damage in the areas of specific geothermal projects

\begin{tabular}{|c|c|c|}
\hline Project & Endangered species & Habitat affected \\
\hline \multicolumn{3}{|c|}{ Geopressure } \\
\hline $\begin{array}{l}\text { Gladys McCall } \\
\text { Sweet Lake } \\
\text { Blessing Prospect } \\
\text { LaFourche Crossing }\end{array}$ & $\begin{array}{l}\text { None } \\
\text { None } \\
\text { None } \\
\text { None }\end{array}$ & $\begin{array}{l}\text { Surrounding marsh } \\
\text { Rice fields used by waterfowl } \\
\text { Grain fields, riparian woods } \\
\text { Marsh, cypress-tupelo swamp }\end{array}$ \\
\hline \multicolumn{3}{|c|}{ Hydrothermal } \\
\hline $\begin{array}{l}\text { Heber Binary Cycle } \\
\text { Rorabaugh } \\
\text { Baca }\end{array}$ & $\begin{array}{l}\text { Flat-tailed horned lizard } \\
\text { Hot springs panic grass } \\
\text { Three state rare plants; }\end{array}$ & $\begin{array}{l}\text { Natural desert vegetation } \\
\text { Oak woodlands } \\
\text { Salamander and elk habitat }\end{array}$ \\
\hline Boise & $\begin{array}{l}\text { Proposed rare plant } \\
\text { species (wild onion) }\end{array}$ & Woodland \\
\hline NCPA No. 2 & $\begin{array}{l}\text { Proposed rare plant } \\
\text { (jewel flower) }\end{array}$ & Seeps and riparian habitat \\
\hline \multicolumn{3}{|c|}{ Hot dry rock } \\
\hline Fenton Hill & None & Elk habitat \\
\hline
\end{tabular}

\subsubsection{Cultural and Socioeconomic}

\subsubsection{Generic impacts}

Except for the use of geothermal surface manifestations (e.g., hot springs, geysers) as religious or cultural resources, the cultural and socioeconomic impacts of geothermal development are not unique when compared to other energy development and utilization projects.

Programmatic documents predicted that potential impacts of geothermal development on socioeconomic factors such as housing, services, and transportation would be the result of the increased workforce required for a particular project and increased vehicular activity necessary to access the site with equipment and materials. Many geothermal developments in the West, Southwest, and Pacific regions are located in areas with sparse populations where significant population increases could stress local services. These areas may also be pristine, in which case the industrial nature (drill rigs, power plants, pipelines, cooling towers, steam plumes, and transmission lines) of geothermal exploration and development can degrade aesthetic qualities.

Geothermal development at sites in proximity to natural or historic landmarks, national parks, archaeological or historical sites, and cultural resources of groups such as native Americans could result in disturbance and potential degradation of these resources. Federal and some state laws require consultation with appropriate responsible agencies and parties regarding historic/cultural resources prior to 
initiation of a project. Such requirements help to identify issues that may be mitigated and sometimes lead to abandonment of the project or selection of an alternative.

\subsubsection{Site-specific impacts}

Most site-specific DOE geothermal projects were expected to create little potential for impact to socioeconomic or cultural resources, except as noted. The Heber demonstration project was identified as one which might have adverse impacts on local housing availability. Aesthetic impacts were predicted for the hot dry rock and geopressure development sites as well as the Baca and Heber demonstration projects, based on the terrain and scenic value of the development areas and the physical nature (e.g., size or land use requirements) of the projects. Archaeological/historic sites and natural areas near these same sites were considered as potentially vulnerable to project activities.

A potential local traffic problem was predicted for the Hawaii Geothermal Well Test project. In addition, mention was made of the likelihood of socioeconomic and cultural resource impacts in the event of a major accident such as a well blowout. Concern was also noted regarding the potential conflict of geothermal development with indigenous religion in the vicinity of the Hawaii project.

The greatest potential cultural impact of any project was identified at the Baca demonstration project in Sandoval and Rio Arriba counties, New Mexico [7]. The project was considered likely to infringe on Indian religious practices in one or more of the following ways: (1) destruction of religious sites; (2) destruction of sacred objects including plants, water, animals, birds, trees, and shrubs; (3) increased opportunity for invasions of privacy; (4) contamination and/or reduction of the availability of water for sacred practices; (5) depletion of the flow of sacred springs; and (6) interference with access to religious sites. However, the full extent of any possible infringement was not predicted because locations of religious sites, dates and times of ceremonies, and other details concerning religious practices were considered privileged information by the native Americans.

\subsection{RECOMMENDED MONITORING AND MITIGATION MEASURES}

\subsubsection{Air Quality}

To minimize ambient air quality impacts of hydrogen sulfide released from geothermal brine/steam during well testing and production, abatement systems that use the Stretford process were recommended. These systems convert hydrogen sulfide to elemental sulfur which can usually be readily disposed of or marketed. For example, use of such a system at the NCPA No. 2 [33] project was predicted to reduce emissions of hydrogen sulfide from a range of 44 to $80 \mathrm{~kg} / \mathrm{h}$ during normal plant operation to a range of 15 to $26 \mathrm{~kg} / \mathrm{h}$. Secondary abatement with hydrogen peroxide/iron sulfate catalyst would further reduce emissions to $2.7 \mathrm{~kg} / \mathrm{h}$, well below the state requirement of $11 \mathrm{~kg} / \mathrm{h}$. 
For all projects, fugitive dust resulting from construction and/or vehicular activity was predicted to be maintained at insignificant levels by graveling and/or frequent spraying of roads and disturbed lands with water or other wetting agents.

Particulates resulting from drift emitted from the cooling tower(s) during power plant operation were to be controlled by drift eliminators. State-of-the-art technology was proposed by DOE for all projects requiring drift eliminators. For the Heber demonstration project, this would involve installation of a system with an efficiency of $99.8 \%$ or better. Selection of drift eliminators for a specific project would ultimately be based on air quality modeling of drift and prediction of subsequent impacts or extrapolation of impact predictions from projects involving similar activities, equipment, and physical/climatic features.

In some cases, DOE committed to air quality monitoring in order to identify significant ambient changes that had not been predicted or to develop baseline data from which long-term project impacts could be measured. At the Hawaii project [1] for example, monitoring of mercury and hydrogen sulfide emissions was recommended because these pollutants were a concern during flow testing. Additional ambient monitoring of mercury, arsenic, hydrogen sulfide, sulfur dioxide, and sulfuric acid was also proposed for the research station [5]. Additional commitment to air quality monitoring was outlined in environmental monitoring plans for all phases of the geopressure program (construction, drilling, and testing).

\subsubsection{Noise}

The major mitigating and corrective measures recommended for decreasing noise produced by geothermal projects include the following:

- use of noisy construction equipment restricted to daylight operation,;

- use of muffled diesel rigs,

- avoidance of air drilling when possible,

- venting of wells through muffled vents or submerged discharge diffusers, and

- selection of sites adequately distant from sensitive noise receptors.

\subsubsection{Groundwater, Geology, and Soils}

\subsubsection{Groundwater}

DOE recommended that mitigation of groundwater contamination be accomplished by preventive and corrective actions. To prevent surface infiltration and leaching, brine or liquid waste storage pits would be constructed with impervious liners to contain potentially toxic substances. Reserve ponds, evaporation pits, and drainage channels also would be lined with impervious material and would have a minimum freeboard height of $1 \mathrm{~m}(3 \mathrm{ft})$. Leakage from well casings could be limited by overlapping and cementing casing sections to a depth of $30 \mathrm{~m}$ 
(100 ft). Annular space of each well would be cemented completely from the formation to the surface to provide greater stability, to ensure sealing of overlying aquifers and fault zones, and to control pressures.

\subsubsection{Soils}

To minimize erosion during construction at geothermal development sites, DOE recommended that careful engineering design and site selection precede initiation of excavation and earth movement. Adherence to sound construction practices was also recommended for all projects. Typical mitigation measures included

- protection of steam gathering lines from contact with the soil;

- use of sulfate-resistant concrete;

- removal or consolidation of soils unsuitable for supporting foundations;

- careful design and grading to minimize cut and fill;

- clearing of areas in stages to minimize exposure time;

- planting of cleared areas with appropriate vegetation; and

- diking of roads and drill pads, directing runoff to settling ponds.

\subsubsection{Geology}

Both induced subsidence and depletion of fluids in the geothermal reservoir could be mitigated by reinjecting as much of the spent produced fluids as possible. In most cases, less than $100 \%$ of produced fluids would be available for reinjection due to evaporation losses. If reinjection into the producing reservoir were not possible (e.g., all geopressure projects), spent fluids would be injected into an overlying aquifer with similar chemical characteristics (especially salinity or dissolved solids) to avoid contamination.

With regard to induced seismicity, recommended mitigating measures included injection by gravity alone, by reducing injection pressures, or by selecting shallower depths for disposal. With regard to impacts due to accidents, in nearly all of the EAs, DOE committed to the use of high-pressure blowout prevention equipment to reduce the potential threat of a well or subsurface blowout to groundwater, geology, and soils. Such equipment was not required in projects involving shallow exploratory wells (less than about $2500 \mathrm{~m}$ ) when the risk of blowout was minimal (e.g., Coso [4]).

DOE also stated its intent to monitor subsidence and seismic activity for numerous projects (e.g., Fenton Hill, Raft River, South Brawley, Roosevelt Hot Springs, Beryl and Lund, and all geopressure projects) and to monitor groundwater quality and quantity to detect contamination as early as possible and to prevent significant lowering of the water table in areas of groundwater scarcity. 


\subsubsection{Surface Waters and Aquatic Ecology}

\subsubsection{Geopressuréd projects}

The several generic and site-specific environmental assessments concerned with development of geopressured resources examined in this retrospective study recommended the following measures for mitigation or monitoring of impacts to surface waters and their aquatic communities:

- avoidance of activities during seasons when wildlife and land uses would be most affected, and avoidance of federally protected lands or habitats for rare, threatened, or endangered species;

- minimization of erosion by graveling (with gravel or shells) or planking roads and other disturbed areas that must remain cleared of vegetation; utilization of existing wells, roads, canals, etc., when possible; reestablishment of natural contours and native vegetation at other disturbed areas; limiting the size of drilling rigs and support facilities to the smallest size possible; stockpiling of topsoil for reuse; and careful alignment of roads parallel to dune ridges;

- use of ring dikes and adequately sized and lined mudpits and reserve ponds around wells and their support facilities to contain all leaks, spills, and runoff other than a large-scale blowout;

- use of nontoxic drilling muds where practicable;

- use of blowout preventers, high-pressure pipes and valves, proper cementing and overlapping of casing, and establishment of a spill prevention and countermeasure plan;

- periodic inspection of dikes, fluid storage tanks, ponds, and pits to lower the potential for accidental spills;

- reinjection of all geothermal brines;

- shutting down or reducing rate of flow of production wells if reinjection wells are inadequate for disposal of all geothermal fluids;

- hydrodynamic and pollutant transport modeling of a specific site to enable prediction of the distribution and fate of geopressured effluents and their constituents; and

- after completion of a given project, removal or disposal of all potentially hazardous fluids and materials, followed by restoration of the site to its natural conditions as nearly as practical.

Several important mitigative measures recommended for only one or two specific projects as follows are listed in Table 3.7. 
Table 3.7. Examples of specific measures recommended for mitigating aquatic impacts of geothermal projects

\begin{tabular}{|c|c|}
\hline Project & Mitigation measure \\
\hline Dow Parcperdue & $\begin{array}{l}\text { Shunt any uncontrolled release of brines away from } \\
\text { sensitive wetlands to less sensitive Vermilion River }\end{array}$ \\
\hline Gladys MeCall & $\begin{array}{l}\text { Use an existing well site and confine all activity to } \\
\text { within site levee and existing plank road; }\end{array}$ \\
\hline Sweet Lake & $\begin{array}{l}\text { Align spoil banks parallel to natural drainage; } \\
\text { permanently block canals after project completion; limit } \\
\text { speed of canal traffic to reduce erosion and sedimentation }\end{array}$ \\
\hline Southeast Pecan Island & $\begin{array}{l}\text { Restore natural drainage by closing canals and } \\
\text { breaching spoil banks after project termination; use } \\
\text { existing reinjection wells }\end{array}$ \\
\hline $\begin{array}{l}\text { Westmorland and Baca } \\
\text { Ranch }\end{array}$ & $\begin{array}{l}\text { Cease irrigation of some agricultural land to } \\
\text { limit water use }\end{array}$ \\
\hline Raft River & $\begin{array}{l}\text { Avoid riffle areas for pipeline crossings; use flexible } \\
\text { pipe or joints to prevent pipeline ruptures in the case of } \\
\text { subsidence }\end{array}$ \\
\hline Rorabaugh & $\begin{array}{l}\text { h-moving operations to rainless days; design } \\
\text { sumps to contain potentially toxic spills }\end{array}$ \\
\hline Marlin & $\begin{array}{l}\text { Retain geothermal fluids in temporarily cooling/settling, } \\
\text { construct stair-step waterfall for aeration of fluids }\end{array}$ \\
\hline Beryl and Lund & Site wells away from playas or washes \\
\hline Coso & Site wells away from springs and seeps \\
\hline
\end{tabular}

\subsubsection{Hydrothermal projects}

The hydrothermal subprogram EA [2] recommended the following measures for mitigation of adverse effects of development on aquatic resources:

- minimization of erosion by revegetation, appropriate diking, trenching, use of mats, retention of buffer strips of undisturbed vegetation, and graveling of roads;

- provision of impermeable linings for sumps;

- appropriate siting of sumps with respect to local topography to reduce effects of runoff;

- environmentally acceptable disposal of liquid construction wastes and other effluents;

- reinjection of spent fluids and cooling-tower blowdown;

- use of settling or evaporation ponds when necessary to protect aquatic resources; and

- use of blowout preventers and related control equipment. 


\subsubsection{Hot dry rock projects}

The hot dry rock subprogram EA [10] suggested several measures that could be taken to mitigate the adverse effects of development on surface waters and aquatic ecosystems and identified areas in need of effective, but as yet unspecified, measures for mitigation. To reduce the impacts of construction-induced turbidity and siltation on streams and their aquatic communities, the following measures were recommended:

- minimization of disturbances of vegetation and soil from the outset;

- graveling of roads;

- retention of vegetation buffer strips;

- appropriate installation of dikes, trenches, and mats to intercept and divert runoff; and

- revegetation of disturbed areas.

Appropriate placement of sumps with respect to local topographic features and the use of impermeable liners was recommended to decrease the risk of sump failure or leakage. Finally, the EA recommended that cooling tower blowdown either be carefully managed for flow rate and quality or diverted to settling or evaporation ponds having impermeable liners.

With respect to the one site-specific project examined in this study (Fenton Hill), releases of circulation water from holding ponds must meet the conditions set forth in a National Pollutant Discharge Elimination System permit. Water treatment and monitoring before release would also likely be necessary according to the EA.

\subsubsection{Land Use and Terrestrial Ecology}

Because of the limited impacts expected on land use and terrestrial ecology, mitigation measures were directed primarily at (1) avoiding unnecessary land use, (2) clarifying uncertainties (e.g., drift effects), and (3) minimizing effects on sitespecific ecological features or important species.

Mitigation measures recommended for geopressure projects were virtually identical. These were discussed in detail by Reed et al. (1983) for the four sitespecific projects which were built. Summarized, they include the following:

- constructing and vegetating a ring levee around the site;

- placing gravel, shell, or boards on roads and well pads;

- installing blowout prevention equipment;

- removing or reinjecting wastes; and

- restoring the site by complete removal of facilities, replacement of topsoil, and revegetation. 
Recommended mitigation measures for other projects were directed at reducing or eliminating disturbance to important species or habitats in the area. With the exception of drift, which is discussed below, these measures are summarized by project in Table 3.8 .

Projects involving power plants (Heber, Westmorland, South Brawley, Rorabaugh, Baca, Raft River, Beryl and Lund, and Roosevelt Hot Springs) all incorporated drift eliminators into their cooling tower designs. For Baca and Raft River, this action was expected to remove drift effects on land use and terrestrial ecology as significant impacts. Those projects for which uncertainty remained were identified in Table 3.5 as subject to potential damage from drift. For these (Heber, Westmorland, South Brawley, Rorabaugh, Beryl and Lund, and Roosevelt Hot Springs), further measurement of cooling water characteristics (e.g., dissolved solids, arsenic, boron, and biocides) and monitoring of drift effects were recommended.

Table 3.8. Specific measures for mitigating impacts to land use and terrestrial ecology recommended for geothermal projects

\begin{tabular}{|c|c|}
\hline Project & Mitigation measure \\
\hline Heber & $\begin{array}{l}\text { Cluster wells to avoid prime farmland } \\
\text { Fence evaporation basin to discourage } \\
\text { wildlife use } \\
\text { Survey potential evaporation pond sites for, } \\
\text { and avoid areas with, flat-tailed horned lizard }\end{array}$ \\
\hline Westmorland & $\begin{array}{l}\text { Route transmission lines to minimize } \\
\text { waterfowl collisions }\end{array}$ \\
\hline Baca & $\begin{array}{l}\text { Avoid elk winter range } \\
\text { Survey potential routes and sites for, and avoid areas } \\
\text { with, salamander and endangered plant habitat }\end{array}$ \\
\hline Boise $0+$ & $\begin{array}{l}\text { Survey potential site for, and avoid areas with, } \\
\text { proposed endangered wild onion }\end{array}$ \\
\hline Raft River & Maintain $50-\mathrm{m}$ buffer on each side of stream \\
\hline Beryl and Lund & $\begin{array}{l}\text { Maintain } 1-\mathrm{km} \text { buffer around butte raptor } \\
\text { habitat }\end{array}$ \\
\hline Rorabaugh & $\begin{array}{l}\text { Implement measures to limit erosion and } \\
\text { sedimentation } \\
\text { Use drains to maintain water supply for } \\
\text { wildlife } \\
\text { Revegetate disturbed areas with native } \\
\text { species }\end{array}$ \\
\hline
\end{tabular}

\subsubsection{Cultural and Socioeconomic}

For all projects, DOE stated its intent with regard to the preservation of archaeological, historical, or cultural resources. Prior to grading and site preparation activities in areas where archaeological resources were known to exist, DOE would require that surface collection samples be taken by a qualified 
archaeologist. Systematic collection would then be conducted if it were determined that artifacts or sites would be affected by construction activity. For major projects, such as Baca, DOE committed to a formalized mitigation plan prior to initiation of the project.

A significant issue resulting from the proposed Baca demonstration project [7] was the conflict of geothermal development with native American resources (Sect. 3.6.1.2). DOE's plans for mitigating the conflict included the following:

- an investigation would be made to determine if the site were related to native American religious sites or ceremonies;

- if the site were currently the subject of religious practices, religious leaders would be consulted to determine whether the proposed activity would infringe on the free exercise of religion;

- if consultation indicated there would be an infringement, alternate plans would be prepared in consultation with religious leaders;

- if no alternate plan were feasible, and a conflict persisted, the DOE Assistant Secretary for Environment would balance the compelling interest of the proposed activity with the infringement on the free exercise of religion; and

- any decision to proceed with the proposed activity would be approved by the Secretary of DOE.

As an alternate plan, DOE proposed the following provisions on which to base a mitigation plan for protecting religious freedoms of native Americans:

- consultation with native American leaders on the design, siting, and construction of power plant facilities, including transmission lines, to minimize impacts on areas of religious significance;

- consultations throughout the operating period of the facility to assure minimum interference with religious rights and practices;

- protection and preservation of religious sites located in the project area or otherwise under the project operator's control;

- guarantees of access to religious sites under the project operator's control;

- prompt notification of native American leaders in case of an accident that may cause contamination of freshwater supplies;

- assistance in identifying areas within the Baca location where religious objects may be collected; and

- consultation on plans for any future geothermal development by the project operators in the Baca location.

Potential socioeconomic problems requiring mitigation were predicted for only a few of DOE's proposed geothermal projects. At Heber, mitigation was recommended 
to reduce the potentially adverse impact of demand for temporary local housing beyond the means of the existing market. It was recommended that advance planning for housing needs and corresponding housing resource requirements be coordinated among the project proponents, county, and local planning officials. To mitigate traffic impacts, carpooling of drilling and construction crews was suggested as a means of decreasing the number of commuting vehicles coming into the project area on workdays. Also, staggering drilling and construction crew work shifts could mitigate traffic problems during the early morning and late afternoon hours. For several projects, including those at the Geysers and the Heber project, it was recommended that above-ground pipes be painted earth-tone colors to reduce visual impacts.

\subsection{SUMMARY}

In general, environmental analyses of geothermal projects portrayed potential impacts as relatively benign in comparison with most other energy-producing technologies. Fewer impacts were predicted, and, when present, their consequences were usually not expected to be serious. In many cases, impacts could be substantially mitigated by appropriate siting, design of facilities, and use of appropriate control technologies.

Environmental impacts of geothermal projects, their probability of occurrence and their severity, are summarized in Table 3.9. Among the potential impacts most frequently cited, and hence judged most likely to occur, were air pollution (particularly by hydrogen sulfide), high noise levels, increased erosion and sedimentation, and use of land for geothermal development. Of these, only air pollution had potential for severe impacts. Even in this case, nuisance odor of hydrogen sulfide was the major impact, and current control technologies were generally predicted to be adequate to reduce impacts to acceptable levels. Impacts with a moderate probability of occurrence included subsidence, water pollution and consumption, local climatic changes, and habitat disturbance. Severity of impacts was anticipated to be high for water consumption and sometimes high for water pollution. Problems with consumption arose because areas in which water was needed for geothermal activities also tended to be areas where supplies were limited and where there were other heavy demands (e.g., irrigation) placed on water supplies. For certain Imperial Valley projects, accelerated salinization of the Salton Sea and potential adverse effects on its fisheries continue to be a concern. Other moderately probable impacts were of low to moderate potential severity, depending on site- and resource-specific parameters. Impacts considered unlikely to occur included seismicity, well blowouts, and cultural and socioeconomic effects. Severity of these impacts was generally highly situation-dependent and could not be easily predicted. Seismicity, for example, could be of a magnitude varying from unnoticeable to that of a major earthquake. The effects of blowouts would depend on brine chemistry, site and area ecology, and the magnitude and duration of the accident. The potential for serious conflicts with native Americans was 
Table 3.9. Estimated probability of occurrence and severity of potential impacts from geothermal projects, as predicted in environmental analyses

\begin{tabular}{|c|c|c|c|}
\hline$\therefore$ & $\begin{array}{l}\text { Probability } \\
\text { of occurrence }\end{array}$ & Resource type & $\begin{array}{l}\text { Severity of } \\
\text { consequences }\end{array}$ \\
\hline Land subsidence & Moderate & $\begin{array}{l}\text { Water-dominated } \\
\text { hydrothermal }\end{array}$ & Variable \\
\hline $\begin{array}{l}\text { Induced seismic activity } \\
\text { (including earthquakes) }\end{array}$ & Low & All & Variable \\
\hline $\begin{array}{l}\text { Air pollution resulting from } \\
\text { discharge of noncondensable } \\
\text { gases (e.g., hydrogen sulfide) }\end{array}$ & High & All & Low to moderate ${ }^{a}$ \\
\hline $\begin{array}{l}\text { High noise levels of drilling } \\
\text { and plant operation }\end{array}$ & High & All & Low to moderate \\
\hline $\begin{array}{l}\text { Chemical or thermal pollution } \\
\text { of surface waters and groundwaters }\end{array}$ & Moderate & All & Moderate to high \\
\hline Well blowouts & Low & $\begin{array}{l}\text { Hydrothermal; } \\
\text { geopressure }\end{array}$ & Moderate to high \\
\hline $\begin{array}{l}\text { Increased erosion and } \\
\text { sedimentation }\end{array}$ & High & All & Moderate \\
\hline $\begin{array}{l}\text { Consumption of water for } \\
\text { cooling purposes }\end{array}$ & High & $\begin{array}{l}\text { Water-dominated } \\
\text { hydrothermal, hot } \\
\text { dry rock }\end{array}$ & High \\
\hline $\begin{array}{l}\text { Use of land for wells, power } \\
\text { plants, transmission lines }\end{array}$ & High & All & Low \\
\hline Short-term climatic changes & Moderate & Hydrothermal & Low \\
\hline $\begin{array}{l}\text { Disturbance of natural habitat; } \\
\text { alteration of ecosystems }\end{array}$ & Low to moderate & All & Low to moderate \\
\hline $\begin{array}{l}\text { Conflicts with cultural and } \\
\text { archaeological values }\end{array}$ & Low to moderate & $\begin{array}{l}\text { All; mainly in } \\
\text { western regions }\end{array}$ & Moderate to high \\
\hline Socioeconomic problems & Low & All & Low \\
\hline
\end{tabular}

${ }^{9}$ Assumes use of drift eliminators on cooling towers and Stretford process or comparable abatement system for hydrogen sulfide control.

demonstrated by the Baca project, although other cultural and socioeconomic problems were generally perceived as of low severity.

Mitigation measures, including proper siting, good construction practices, sound plant design, and control technologies, were recommended for most of the impacts in Table 3.8. Proper site selection could avoid or lessen disturbance of natural habitats, conflicts with cultural and archaeological values, and the potential for water pollution. Proper siting could also lessen the severity of consequences for air pollution, noise, water pollution, and use of land. Good construction practices could minimize minor air pollution from fugitive dust and limit erosion and sedimentation. Plant and well field design could limit land use (e.g., by clustering wells) and pollution probabilities (e.g., by use of sumps). Control technologies are available for reduction of air pollutants (including hydrogen sulfide and drift), 
noise, and prevention of blowouts. In addition, the technology for reinjecting spent geothermal fluids, available from the oil and gas industry, was refined and applied to geothermal brines. Reinjection greatly lessened concern over waste disposal as a major impact and reduced the probability and degree of subsidence.

For projects in the geopressured zone, these conclusions must be qualified somewhat. Although individual test wells were not expected to have serious impacts, extensive development could threaten important biological resources. Construction effects, subsidence, and well blowouts associated with larger projects located in the coastal region of Texas and Louisiana could seriously alter the circulation patterns, water chemistry, and thermal regimes of coastal wetlands, with consequent adverse effects on the abundance of commercially and ecologically important organisms (e.g., fish, shrimp, crab, and oysters). Mitigation measures could only partially reduce the probability and degree of such impacts.

The environmental documents reviewed in this section took account of both sitespecific analyses and the current state of knowledge regarding impacts of geothermal development. Because geothermal development was and is relatively limited, both in this country and elsewhere, there is a need to verify the nature and extent of predicted impacts. It is important to establish which of the projects covered by environmental analyses were carried out and, for those that were, how the observed impacts actually compared to predictions. The results of these tasks are reported in Sects. 4 and 5. 


\section{CURRENT STATUS AND ENVIRONMENTAL CONCERNS OF ACTIVE DOE GEOTHERMAL PROJECTS}

\subsection{INTRODUCTION}

This section reports the status of existing DOE geothermal projects and reviews known environmental impacts, monitoring, and mitigation by project. A comparison with predictions and recommendations made in the corresponding environmental impact statement (EIS) or EA is included where possible. The purpose of this phase of the study was to

- ascertain which predicted impacts had or had not occurred;

- verify that recommended or other appropriate mitigation and monitoring had been conducted;

- identify analytical limitations in the EA or EIS; and

- contribute to the literature on actual environmental impacts of geothermal development.

The following discussion is ORNL's staff assessment, which is based on telephone and personal contacts with government and industry personnel (Table 2.2). The organization and presentation of results for the projects varies according to the nature and detail of available information.

\subsection{CURRENT STATUS OF DOE GEOTHERMAL PROJECTS}

The current status of extant DOE geothermal projects is given in Table 4.1. The general nature of expected environmental concerns, excluding potential effects of accidents, is also stated. Of the 24 specific projects for which EAs "were written and which were reviewed in Phase $I, 16$ still exist. None of the cancelled projects for which an EA was issued is known to have been terminated for environmental reasons. Only eight of the remaining projects are currently operational, of which three are geopressure test wells, to be decommissioned within the next two to three years. Of the nonoperating projects, only the Raft River pilot plant and test loop has been carried through to completion. The Hawaii test facility is operational but is the subject of litigation regarding effects of future development on local ambient air quality (hydrogen sulfide concentrations) and noise. Other projects are in early stages of design, exploration, or construction. 
Table 4.1. Current status and possible environmental concerns of DOE geothermal projects

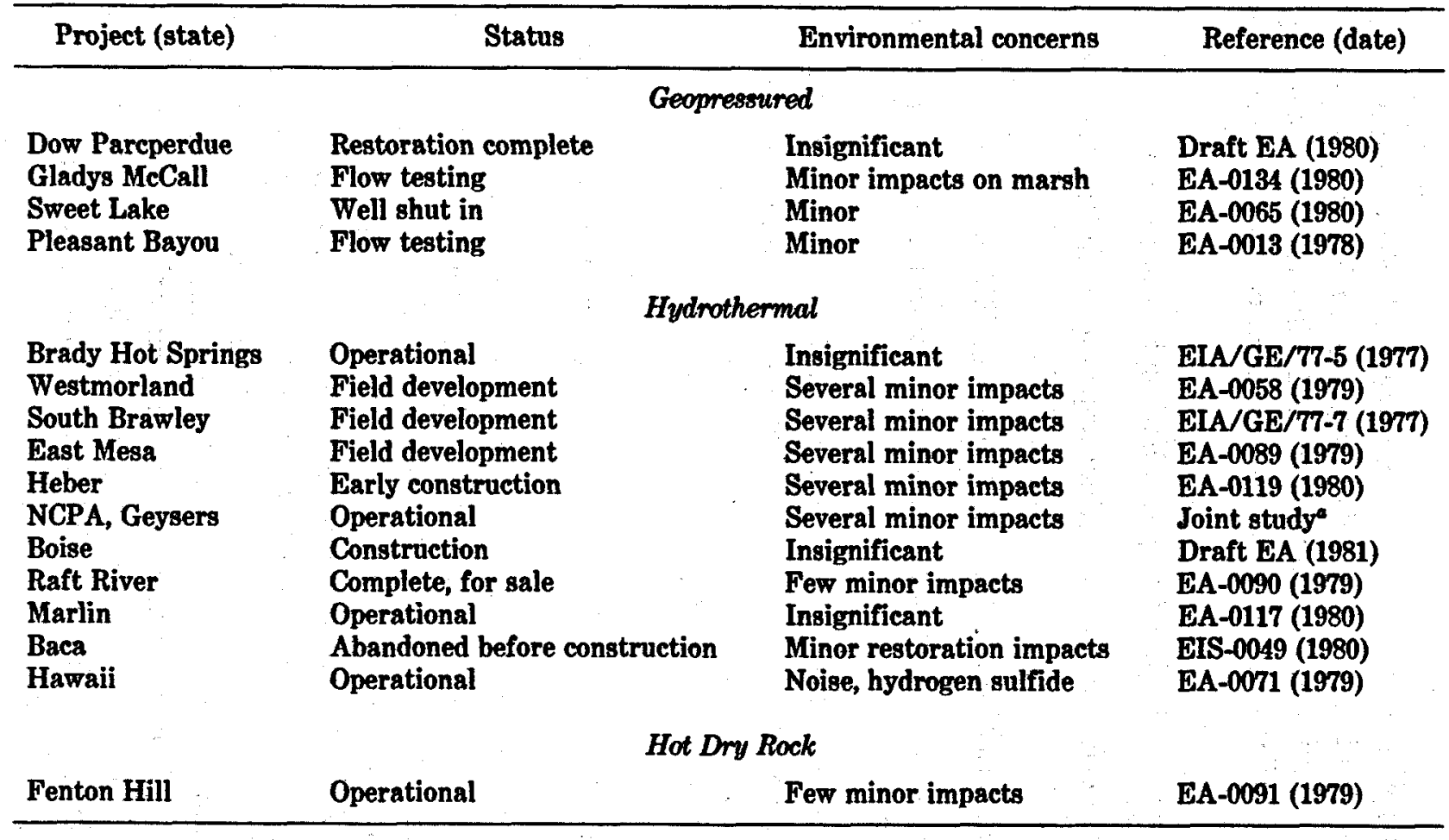

'Northern California Power Agency, NCPA Na. 2 Geothermal Power Plant, Final Joint Environmental Study. 


\subsection{ENVIRONMENTAL CONSIDERATIONS OF DOE GEOTHERMAL PROJECTS}

\subsubsection{Hawaii}

\subsubsection{Impacts}

The Hawaii Well Test and Research Station projects $[1,5]$ involved the drilling of one geothermal well, testing of the physical and chemical characteristics of the resource, and the construction and operation of a power plant to generate approximately $3 \mathrm{MW}$ of electricity. To date, there has been

- no violation of ambient air quality standards,

- noise levels less than $100 \mathrm{dBA}$ at the nearest sensitive receptors,

- no degradation of groundwater or surface water (catchment basins),

- no significant conflict with cultural resources, and

- no significant socioeconomic impacts.

As predicted, hydrogen sulfide emissions were frequently noticeable (by odor) during well testing and are occasionally noticeable during power plant operation when the turbine is down and the steam is vented to the atmosphere, bypassing the primary hydrogen sulfide abatement system (incinerator-scrubber). Ongoing monitoring at the site and at stations in nearby residential areas has recorded a maximum hydrogen sulfide level of less than 50 ppb during worst-case conditions (open venting). This level produces a detectable odor and exceeds California standards of $30 \mathrm{ppb}$. (There are no federal or Hawaii state standards for hydrogen sulfide.) There is no evidence to suggest that such levels present health hazards.

Noise levels from the venting of steam have been minimized by a rock muffler. The hum of machinery is audible at the plant boundary but not at sensitive receptors (e.g., nearby houses, hospitals, schools). A loud rumble audible at a distance of 900 to $1000 \mathrm{~m}$ is evident during plant start-up and well clean-out and lasts about $1 \mathrm{~d}$. A noise resembling a sonic boom is also heard at the same distance during steam-cleaning of pipes. However, these noise levels are attenuated to acceptable levels over the distance between the plant and nearby residential areas, as indicated by results of noise monitoring.

\subsubsection{Mitigation and monitoring}

Mitigation measures recommended by DOE in its EAs included

- iron catalyst or Stretford process for hydrogen sulfide abatement,

- standard noise mufflers for equipment/machinery and for vented steam, and

- careful scheduling of operations to minimize noise impacts.

The hydrogen sulfide abatement system actually used at Hawaii is an incinerator-scrubber $(\mathrm{NaOH})$ that is reported to be $99.9 \%$ efficient. Noise from 
vented steam is attenuated by a rock muffler. Standard engineering design mufflers are used on equipment and machinery. Operations producing the highest noise levels are conducted only during daytime hours.

Monitoring at and near the Hawaii site has included measurements of air and surface water quality and ambient noise levels. The monitoring program has revealed no standards violations and no significant impacts.

\subsubsection{Imperial Valley, California}

\subsubsection{Impacts}

The four extant projects in the Imperial Valley (Heber [9], Westmorland [29], East Mesa [30], and South Brawley [25]) are still in early stages of development. All projects are to consist of testing, field development, and construction and operation of power plants ranging from 48 to $55 \mathrm{MW}(e)$. Minor, short-term impacts which were predicted and have occurred for all four projects include

- fugitive dust from traffic and excavation;

- noise greater than $100 \mathrm{dBA}$ from drilling, testing, and operation of heavy equipment;

- minor pollutant emissions from vehicles and equipment; and

- infrequent hydrogen sulfide odor during flow testing.

Although the potential for subsidence and induced seismicity will exist throughout the life of the projects, state and county officials expect the probability for both to be quite low. As predicted, impacts due to increased construction traffic have not been significant.

\subsubsection{Mitigation and monitoring}

Mitigation measures which were recommended and have been instituted for all projects include

- use of modern vehicles/equipment with pollution control devices,

- spraying and/or gravelling of unpaved areas to reduce fugitive dust,

- use of modern mufflers on vehicles and equipment to reduce noise, and

- scheduling of operations during daytime hours.

Monitoring of subsidence and seismicity is performed throughout the Imperial Valley in a network involving the U.S. Geological Survey, California Division of Oil and Gas, and Imperial County. Independent monitoring may also be conducted by developers; for example, Chevron is presently monitoring seismicity in the Heber field. Ambient air quality monitoring is performed by the Imperial County Air 
Pollution District for the State of California. Water quality is regulated by permits and orders of the regional office of the California Division of Water Resources.

\subsubsection{Geopressure Projects, Texas and Louisiana}

\subsubsection{Impacts}

The four geopressure projects (Pleasant Bayou [14] Sweet Lake [19], Gladys McCall [21], and Dow Parcperdue [20]) consist of well drilling into the geopressured geothermal zone $(3000$ to $4000 \mathrm{~m})$, testing of physical and chemical characteristics of the resource, and the production and sale of natural gas. All wells have been drilled and have been tested to varying degrees.

Actual impacts were less severe than impact predictions in the EAs for these projects. Minor, short-term impacts that were predicted and occurred for all four projects included

- fugitive dust,

- gaseous vehicle/equipment emissions,

- limited erosion, and

- noise levels above $100 \mathrm{dBA}$.

In addition, contamination of a small area of marsh water and sediment may have occurred at the Gladys McCall site as a result of disposal of drilling mud in an unlined pit. The Dow project was completed in an environmentally acceptable manner and the site restored to its original condition (Reed et al. 1982). Temporary minor soil contamination and degradation of groundwater because of a torn liner in the brine storage pit was experienced but not to the extent that vegetation or wildlife was or is likely to be affected. Prompt removal of contaminated soil and reinjection of fluids remaining in the brine pit prevented widespread, long-term contamination.

\subsubsection{Mitigation and monitoring}

Despite recommendations in the EAs, the geopressure projects did not require hydrogen sulfide abatement systems because concentrations were low enough to allow flaring of the gas without violating standards. Mufflers on vehicles and equipment minimized noise to acceptable levels at sensitive receptors. Brine storage and drilling mud disposal pits were lined at the Dow site but unlined at Pleasant Bayou and Gladys McCall.

Monitoring recommended and actually conducted included

- air quality,

- groundwater,

- surface water, 
- noise, and

- seismicity and subsidence.

Air quality and water quality monitoring yielded data that indicated no significant change in ambient levels of pollutants. Noise monitoring at Pleasant Bayou provided information that corresponded well with predictions derived from noise modeling; that is, noise levels due to well drilling and testing at the geopressure project sites were within acceptable levels at sensitive receptors. As a result, noise was not monitored at the other three project sites.

Seismic and subsidence monitoring has continued for all four projects. Air quality monitoring recommended in the EA was not conducted at the Gladys McCall site, because monitoring at other sites demonstrated that impacts were negligible. Water quality monitoring was discontinued in $\mathbf{1 9 8 2}$ for the Pleasant Bayou project, because no significant impact was found after several years of data collection.

\subsubsection{Marlin, Texas}

The Geothermal Direct Heat Project in Marlin, Texas [8], began flow testing in late 1979 and operational testing in early 1982 . The most important environmental issues associated with construction and operation of the project were drilling noise and surface disposal of geothermal fluids. Impacts thus far have largely supported predictions made in the EA. Because drilling operations had to be completed to determine the suitability of the geothermal fluid for surface disposal, the noise issue was essentially resolved before the EA was prepared. The use of an especially large muffler arid other precautions taken during drilling were found to reduce noise at the hospital (less than $10 \mathrm{~m}$ from operations) to tolerable levels. No complaints were received from patients or residents during the three months of drilling and construction.

Drill cuttings, which were not hazardous, were removed to an approved disposal site, and other nonhazardous solid waste was hauled to the city landfill (Conover et al. 1983). During construction and flow testing (prior to completion of the EA) runoff and geothermal fluids contaminated with drilling mud, mud additives, and other suspended solids flowed via the city storm-water drainage system into an artificial storm-water catchment and then via a small creek into a slough. The slough in turn drains to the Brazos River. Impacts on these aquatic systems were mitigated by using drilling muds with only nontoxic additives and by the relatively long residence time of geothermal fluids in the catchment basin, which permitted cooling and settling of suspended solids before entering natural waterways.

The catchment basin was only one-half the depth and area it was first believed to be, but residence time for the spent fluids was sufficient because the fluid was already quite cool by the time it entered the basin. The fluid's greater density (due to salinity) caused it to flow along the bottom of the basin with little mixing until it approached the outfall into Bean Branch, whereupon it became well-mixed. 
One other mitigative measure described in the EA, the stair-step waterfall for aeration of the spent fluids before entry into the catchment basin, has not been built. The maximum height available for a waterfall was subsequently found to be too low to significantly enhance aeration. In any event, no adverse effects beyond the catchment basin have been observed.

With respect to surface disposal of geothermal fluids produced during operations, the EA predicted chemical degradation of waters and associated aquatic life in the catchment basin but no significant impacts on other downstream surface waters or their aquatic communities. These predictions are partially supported by chemical and biological monitoring conducted since operations began (Conover et al. 1983); the catchment basin is a highly stressed system (although not completely devoid of fish and other aquatic life) whereas sampling further downstream revealed no evidence of adverse effects on water quality or aquatic life. Because no baseline (predischarge) data were collected, however, the degree to which the catchment pond owes its stressed condition to geothermal discharges cannot be ascertained. Nor can it be stated with any certainty that subtle changes in aquatic communities of the creek or slough have not occurred. In any event, the discharged geothermal fluids must satisfy the requirements (water quality standards of the Texas Water Development Board) of a discharge permit issued by the Texas Railroad Commission as well as those of an NPDES permit issued by the U.S. Environmental Protection Agency. Spent fluids are monitored monthly.

The experience with this project's operation so far generally supports the predictions made in the EA. It also underscores, however, the importance of adequate baseline monitoring before commencement of construction and operation, particularly with respect to aquatic resources, since the highly stressed condition of the catchment basin could not be attributed to a particular source with any certainty. Further characterization of Bean Branch and McCullough Slough (both before and since operations began) was also warranted to permit an adequate evaluation of their importance as aquatic resources and to establish a basis for predicting and detecting adverse effects of project construction and operation.

\subsubsection{Brady Hot Springs, Nevada}

The Geothermal Food Processors project at Brady Hot Springs, Nevada [25], has been in operation since 1979 . No substantive adverse effects on the environment have been observed, as was predicted by the EA. In particular:

- flow testing did not exceed the capacity of the catchment basin,

- hydrogen sulfide emissions have not been a problem,

- nothing of archaeological value was discovered,

- interference of operations with grazing has not occurred because adjoining lands are salt flats unsuitable for grazing,

- no adverse effects of noise on Fernley Wildlife Refuge or nearest residents have been observed, 
- no ground subsidence has been noted,

- no accumulation of constituents of geothermal fluid to levels toxic to wildlife or waterfowl have been noted, and

- no accidental spills or blowouts have occurred.

Most of the mitigative measures recommended by the EA appear to have been implemented. Access roads and the parking lot were paved to reduce dust. Waste vegetable matter is trucked to a farm and used to feed pigs. Although not planned as a mitigative measure, plant operations are limited to approximately $150 \mathrm{~d}$ each year from late spring (May) to early fall (October) as described in the EA. This schedule limits atmospheric emissions to the period of most active atmospheric dispersion.

One substantive change from operations as described in the EA concerns reinjection. All process and geothermal fluids were to be reinjected after removal of solids; instead, the fluids are allowed, by a state permit issued in December of 1978, to flow from the cooling pond into a large salt flat where they evaporate. Some of the fluid probably percolates into the ground. The rationale for surface disposal, according to the Division of Environmental Protection, Nevada Department of Conservation and Natural Resources, is that the geothermal fluids naturally surfaced via a flowing artesian well prior to construction of the geothermal project. In any case, surface disposal to a salt flat is unlikely to constitute a significant source of adverse environmental impacts.

\subsubsection{Fenton Hill, New Mexico}

The Fenton Hill Hot Dry Rock Project [11] has been operating to some extent since 1977. Generally, the construction and operating experience at Fenton Hill supports the assessment presented in the EA that no significant impacts were likely to occur. Problems have arisen over disposal of wastewater and possibly over water availability, as discussed below.

The EA stated that future surface disposal of wastewater into the dry arroyos would be regulated under an NPDES permit requiring treatment and removal of harmful constituents before release. However, as actually issued, the permit only requires monitoring of constituents in the discharge. No limits on the concentrations or quantities of constituents discharged and no treatment before the approximately yearly releases are required. The only treatment the wastewaters currently receive is settling in the holding ponds. Although the EA stated that no drilling fluids would be released, the wastewater does contain supernatant from drilling muds. In addition, elevated concentrations of sodium, lithium, boron, arsenic, and cadmium sometimes occur (Purtymun et al. 1981). Finally, the presence of a high-quality aquifer separated from the facility only by some $130 \mathrm{~m}$ of highly permeable strata caused New Mexico to request a groundwater discharge plan be submitted to the Oil Conservation Division of the State Energy and Minerals Department. According to the state, implementation of such a plan should 
eliminate surface discharge beyond an evaporation basin. A plan has been submitted, but concern has arisen that compliance with discharge limitations may be difficult.

Impacts of surface discharge were predicted to be, and appear to have been, minimal. The quantity of fluid discharged in 1980 was slightly lower than that predicted in the EA. Except for some indication of lithium and boron accumulation in vegetation in the arroyo within $400 \mathrm{~m}$ of the site, no adverse effects on biological and surface or groundwater resources (Purtymun et al. 1981) have been observed, which is consistent with EA predictions. Monitoring to detect any undesirable effects of surface discharge is being conducted as recommended in the EA.

The EA also indicated that water requirements for the project may eventually exceed the quantity of groundwater locally available to the project. The staff at Los Alamos agree that the $18,500 \mathrm{~m}^{3} /$ year guaranteed by the New Mexico State Engineer may not adequately supply future needs.

Furthermore, it is not yet clear whether the groundwater pumped to supply the project is recharged by water from the Rio Grande system alone, or from both the Jemez River system as well as the Rio Grande (the project lies approximately on the divide between these two systems). If the Jemez River system is shown also to recharge the aquifer being pumped by the project, then the operators will have to buy additional water from someone willing to sell it to compensate for losses from the river.

To help meet future water requirements for the project, a $20,000 \mathrm{~m}^{3}$ polyethylene-lined storage lagoon has been built. Water is being imported by truck to supplement the onsite groundwater supplies. A water rights suit recently filed in federal court by a group of Indian tribes further complicates the water supply question. A ruling in favor of the Indian tribes conceivably could interfere with groundwater use at the Fenton Hill project.

Drilling muds and cuttings are permanently buried in a mud pit using standard techniques common to oil well drilling. Although this practice may be at variance with that described in the EA, which stated that cuttings and muds would be disposed of offsite, the adverse effects are reported to be negligible. Other nonhazardous solid wastes, such as trash, are hauled offsite to an approved county landfill for disposal.

No adverse effects on the terrestrial environment have been observed beyond the immediate areas of construction and operation, as predicted by the EA. The EA did advance the possibility that physiological drought might be induced in vegetation in the thermal plume in the immediate vicinity of the project, but no adverse effects have so far been observed. Although the project is surrounded by good elk habitat, and, indeed, lies in the middle of an elk migration route, again, no adverse effects on the elk have been seen. This is consistent with the EA's projection that anything more than avoidance by elk of the immediate area of the project would be unlikely. 


\subsubsection{Boise Geothermal Limited, Idaho}

Most construction on the Boise geothermal project [35] was completed by February 1983. The project has operated at a relatively low level since then. Overall, the limited operational experience at Boise to date supports the EA's finding of no significant environmental impacts. Minor impacts which were predicted and have occurred include noise during construction and drilling and a slight odor of hydrogen sulfide near the facility. Casual visual checks and monitoring drawdown in other area wells have revealed no subsidence or seismicity. Benchmarks reportedly have been established to aid in detection of subsidence. The geothermal resource appears to lie in a reasonably firm geologic formation. There was no disturbance of historic or archaeological resources at the site, an old military reserve. A survey indicated no specimens of the wild onion proposed for federal listing as an endangered species existed on the well site.

With two exceptions, no changes, deletions, or additions to recommended monitoring or mitigation measures are known to have been made. Such measures have included

- disposal of drilling muds (nonhazardous) in an offsite city landfill,

- onsite burial and covering of other nonhazardous solid wastes,

- monitoring of drawdown in area wells, and

- monitoring of water quality in the Boise River.

Exceptions to the recommendations include the following:

- The EA stated that standard blowout preventers would be used on all wells. Standard blowout preventers were not used, however (some blowout prevention equipment was provided, and prudent procedures followed), because the pressure and temperature of the resource is relatively low. No blowouts or other uncontrolled releases have yet occurred. Scheduled releases during flow testing (approximately $5 \mathrm{~m}^{3} / \mathrm{min}$ ) were adequately contained in the storm basins as predicted by the EA. Fluid chemistry was not determined. The fluid was eventually released to the Boise River. No adverse effects on the river or its biota were evident.

- Unusually high river flows have thus far prevented installation of a planned discharge diffuser in the Boise River for disposal of geothermal fluids. However, the high flows presumably have aided diffusion and no adverse effects on water quality or aquatic life of the Boise River is yet evident.

Two impacts were at variance with predictions in the EA. First, the probability of interference with other wells was expected to be minimal, but a drawdown of 2 to $3 \mathrm{~m}$ has already been reported at one well less than $1 \mathrm{~km}$ away as a result of operations at the project. Although this drawdown at a single well is reported to be insignificant, it should be noted again that the project has operated for a short time only, and at a relatively low level. Further interference, therefore, may be a 
reasonable possibility when the facility approaches full capacity for long periods. On the other hand, project operation may tend to mitigate (by lowering internal pressures) the vertical leakage from deep geothermal systems to surface waters or near-surface aquifers currently believed to be occurring naturally. To protect against project-related leakage, all wells have been cased to below the levels of shallow (water table) aquifers as stated in the EA. A water level and water quality program was established in October of 1982.

Secondly, all four sites proposed for potential drilling operations were or are being drilled. The EA had stated that use of more than one drilling site was unlikely. The temporary disturbance of the four sites in the Military Reserve Park resulted in a minor conflict over aesthetics with the City Parks Department, which was resolved through burial of about $75 \%$ of each pumphouse and revegetation and restoration of the rest of the disturbed areas by the Parks Department.

\subsubsection{Northern California Power Agency No. 2 (NCPA No. 2)}

NCPA No. 2 [33] came on line in 1982. Its brief operating life has been characterized by many start-ups and shut-downs because of recent surpluses of hydropower. Currently, it has been operating at about $75 \%$ of capacity but will soon be operating at near full capacity. So far, no significant adverse environmental impacts have been discerned beyond the immediate area of the geothermal facilities. One accidental spill occurred when a pipeline carrying a mixture of steam condensate and rainwater ruptured. This fluid was being transported from the reinjection basin to a construction area for use in compaction. Most of the spill was trapped in a sedimentation basin, but about $800 \mathrm{~L}$ escaped to a tributary of Big Sulphur Creek. Because much of the fluid was rainwater, its water quality was reported to be better than the tributary's water quality; consequently, no significant impacts were expected or observed.

A natural seep for which some concern was expressed in the Joint Environmental Study (JES) [33] has generally remained free of contamination with the possible exception of minor inputs from cooling tower drift. The seep was believed to be of some importance as a source of water to local wildlife. In compliance with a recommendation in the JES, a concrete water storage basin and drinking facility for wildlife has been built to mitigate any adverse effects on the seep as a watering hole.

Other recommended measures for mitigating or monitoring the potential effects of project construction and operation generally have been implemented:

- revegetation of all disturbed areas;

- reinjection of liquids, including storm runoff collected around power plant or at well pads;

- monitoring of offsite runoff following each storm event;

- construction of a sedimentation basin; 
- submission of a Spill Prevention Contingency and Containment Plan to the California Water Quality Control Board;

- construction of a $1700 \mathrm{~m}^{3}$, lined spill retention basin around the cooling towers and installation of water level indicators in the towers;

- use of existing roads where possible;

- stair-stepping of slopes and construction of runoff diversion channels;

- maintenance of a 90-m-wide undisturbed buffer zone on either side of the unnamed tributary;

- participation in the Geysers Aquatic Resources Monitoring program involving area monitoring of erosion, heavy metals, phosphate, sulfate, dissolved oxygen, and fish populations in area streams;

- use of drift eliminators (99.998\% efficiency);

- monitoring of radon, arsenic, mercury, boron, hydrogen sulfide, and ammonia in geothermal steam, and these contaminants plus total suspended particulates and vanadium in ambient air;

- installation and monitoring of a hydrogen sulfide abatement system;

- monitoring of vegetation plots for boron concentrations and effects;

- offsite disposal of potentially toxic wastes (e.g., drilling muds) at an approved Class II-I waste disposal site; and

- monitoring of state-listed uncommon, threatened, or endangered plants for adverse effects.

Some changes in recommended mitigation or monitoring have been made. For example, a solids removal system for the hydrogen sulfide abatement system was found to be unnecessary because sulfates remained in solution and were, therefore, simply reinjected with other fluids. In addition, project staff are attempting to delete the current requirement for monitoring sour gas entering the hydrogen sulfide abatement system, because only the gases exiting the system are environmentally important. This system has kept hydrogen sulfide emissions far below the standard established by the North Sonoma County Air Pollution District, although upset conditions occasionally required shutdown of the plant. Finally, recommended stockpiling of topsoil for later replacement was found to be unrealistic because so little topsoil exists at the site.

No blowouts, landslides, or problems with noise have occurred thus far. In some respects, this project and others at the Geysers field may have had some beneficial environmental effects:

- guard-houses and other project-related barriers to public access have reduced poaching and damage from off-the-road vehicles;

- removal of the cattle has reduced overgrazing, permitting revegetation and some alleviation of erosion-related problems; 
- stabilization of existing roads has partially alleviated erosion; and

- a burning program has been established to increase production of appropriate foods for wildlife.

In summary, no significant adverse environmental effects related to construction and operation of the NCPA No. 2 geothermal project have been demonstrated. The project, however, has been operational for a brief time only, long-term and cumulative effects, particularly on vegetation and air quality, are unknown.

\subsubsection{Raft River, Idaho}

The Raft River Geothermal Program [3, 6] at the Idaho National Engineering Laboratory was designed to demonstrate both direct-use applications and electricity generation from moderate-temperature geothermal fluid. A comprehensive program of environmental assessment, monitoring, and protection was a part of the demonstration. The results of the environmental work are reviewed by Thurow and Cahn (1982). No major environmental impacts resulted from development of the Raft River Geothermal Research Facility. Potential concerns which had been identified (Sect. 3) included:

- air emissions (TSP),

- induced seismicity and subsidence,

- effects on water quality and hydrology,

- raptor disturbance, and

- disturbance of historic and archaeological sites.

Emissions from the geothermal development were measured as being well below National Ambient Air Quality Standards, air quality in the area being affected mainly by agricultural activities. Changes in groundwater quality were negligible. Short, transient, groundwater-pressure responses were noted during geothermal production and reinjection, but values returned to normal when these activities ceased. There were no spills of geothermal fluids into the Raft River, and no other measured effects on surface waters. The nesting success of ferruginous hawks in the valley was not impaired by geothermal and associated human activities, provided a minimum $0.6-\mathrm{km}$ buffer zone was maintained around nest sites. No increase in seismicity was detected as a result of geothermal development. Although subsidence has been occuring in the valley because of excessive pumping of groundwater, no elevational changes resulting from geothermal activities were detected. There was no impact on known historic or archaeological sites, and socioeconomic effects were minimal as a result of proper planning. 


\subsubsection{Baca, New Mexico}

The Baca Demonstration Project [7] was intended to demonstrate operation of a 50-MW power plant using geothermal fluid. The project was abandoned in 1981 when difficulty was encountered in supplying the required amount of steam (Kerr 1982). The impacts of the project were limited to land disturbance from well drilling and preconstruction activities. In addition to small areas required for 31 drilling attempts (including preproject drilling), the following areas were disturbed:

- the intended plant site (about $8 \mathrm{ha}$ ),

- meteorological tower laydown area (about $1 \mathrm{ha}$ ),

- concrete batch area (about 1 ha), and

- rock quarry (about 5 ha).

No clearing or disturbance for transmission lines occurred. In conjunction with abandonment, the disturbed areas were fully or partially restored in accordance with wishes of the private landowner. Structures which were left include a concrete wall retaining the hill above the plant site, the portion of the quarry existing before the project, and a sedimentation pond between project activities and nearby Redondo Creek. Restoration of the site appears to have adequately minimized the possibility of erosion and sedimentation following abandonment. Hence, the actual impacts of the project were negligible, with adequate reclamation. 


\section{CONCLUSIONS}

Two general conclusions emerge from this survey of environmental impacts of DOE geothermal projects:

- the survey confirms the generally minor nature of impacts; and

- the survey demonstrates the importance of environmental analyses, early environmental planning, baseline and subsequent monitoring, and the comprehensive use of mitigation measures.

The only impacts which were not anticipated by the project EAs were (1) additional land requirements from the use of four drillsites instead of one and (2) the drawdown of area wells at Boise. The only discrepancy between recommended and implemented mitigation was at the Dow Parcperdue well, where inadequate attention to storage pit liners could have caused temporary soil contamination. Other discrepancies either proved insignificant or adequate substitutes were found. In general, the EAs appeared appropriately conservative and reasonably accurate in assessing the nature and severity of impacts.

The survey revealed a number of mitigation measures which have been implemented at projects, with consequent reductions in environmental impacts. Frequently encountered areas for monitoring and mitigation included, in general:

- noise reduction,

- drift eliminators,

- groundwater and surface water monitoring,

- seismicity and subsidence monitoring,

- fugitive dust reduction,

- erosion and sedimentation reduction,

- blowout prevention, and

- spill and waste retention.

The importance of these and other methods for maintaining the relatively benign nature of geothermal energy utilization cannot be overemphasized.

Three provisos must accompany the above conclusions. First, this survey of actual impacts was clearly not exhaustive. Also, a limited number of projects, with short or no operating history, were available for verification. As more and larger projects become operational, the frequency and magnitude of departures from predictions may increase. Under these circumstances, the verification of actual impacts in comparison with predictions, as conducted here, assumes increasingly greater importance. Finally, many impacts, such as the probability and effects of blowouts, involve substantial unknowns and were predicted in a generic manner even in site-specific EAs. It is clear, however, that early analyses of environmental 
problems, although uncertain, and subsequent planning for appropriate mitigation or monitoring, can contribute substantially to avoidance of environmental degradation.

In addition to the above two conclusions, a few generalizations can be made about the environmental impacts of geothermal energy. These are

- accidents involving spills are the most serious concern, potentially threatening surface water and groundwater, terrestrial and aquatic biotic communities, and air quality;

- noise associated with drilling and production is a persistent feature of all geothermal activities;

- effects due to $\mathrm{H}_{2} \mathrm{~S}$ and cooling tower drift are a frequent possibility, and methods for predicting impacts require further development;

- all projects involve a suite of construction-related impacts (e.g., erosion and fugitive dust emission) that are similar to those for any energy-development project; and

- solid wastes (e.g., descaling sludge and $\mathrm{H}_{2} \mathrm{~S}$ control) may involve hazardous materials and must be disposed of properly.

Despite these generalizations, site-specific assessment of environmental impacts remains imperative, both because the nature and extent of emissions can differ substantially and because the receiving systems differ in their susceptibility and their importance to man. Moreover, as geothermal development proceeds, consideration of the cumulative impacts of additional projects will become increasingly important $[7,30,34]$. 


\section{REFERENCES}

Beeland, G. V. and D. B. Boles. 1981. The Potential Effects of Environmental Regulatory Procedures on Geothermal Development. DOE/ET/27208-T2. U.S. Department of Energy, Division of Geothermal Energy. January.

Castle, R. W. 1975. Observations of the Intracoastal City, Louisiana, Gas Well Blowout and Oil Spill, report to URC Research Company.

Conover, M. F., T. F. Green, R. C. Kenney, P. F. Ellis II, R. J. Davis, R. C. Wallace, and F. B. Blood. 1983. Direct Utilization of Geothermal Energy for Space and Water Heating at Marlin, Texas: Final Report. DOE/ET/27059-1. Radian Corporation, Austin, Tex.

Cushman, R. M., D. W. Barnes, and R. B. Craig. 1980. "Effects of Geothermal Effluents on Aquatic Ecosystems." Envirom. Int. 4, 209-16.

DOE. 1978. Environmental Assessment Geothermal Energy, Geopressure Subprogram, Gulf Coast Well Testing Activity, Frio Formation, Texas and Louisiana. DOE/EA-0023, vols. 1 and 2.

D0I. 1973. Final Environmental Impact Statement for the Geothermal Leasing Program, vol. 1. Washington, D.C.

EPA. 1974. Information on Levels of Environmental Noise Requisite to Protect Public Health and Welfare with an Adequate Margin of Safety. Report No. 550/9-74-004.

EPA. 1976. Quality Criteria for Water. EPA-440/9-76-023, Washington, D.C.

Goldsmith, M. 1976. Geothermal Development and the Salton Sea. EQL Memorandum No. 17, Environmental Quality Laboratory, California Institute of Technology, Pasadena, Calif.

Gustavson, T. C. and M. M. McGraw. 1977. Ecological Implications of Geopressured-Geothermal Energy Development, Texas-Louisiana Gulf Coast Region FWS/OBS-78/60. U.S. Fish and Wildlife Service Report.

Hartley, R. P. 1978. Pollution Control Guidance for Geothermal Energy Development. EPA-600/7-78-101. Industrial Environmental Research Laboratory, U.S. Environmental Protection Agency. Cincinnati, Ohio.

Kerr, R. A. 1982. "Extracting Geothermal Energy Can Be Hard." Science 218, 668-69.

Kharaka, Y. K., E. Callender, and R. H. Wallace, Jr. 1977. "Geochemistry of Geopressured-Geothermal Waters from the Frio Clay in the Gulf Coast Region of Texas." Geology 5, 241-44.

Mackin, J. G. 1962. "Canal Dredging and Siltation in Louisiana Bays." Publ. Inst. Mar. Sci Uni. Tex. 7, 262-314. 
Morton, J. W. 1977. Ecological Effects of Dredging and Dredge-Spoil Disposal: A Literature Review. Technical Paper No. 94, U.S. Fish and Wildlife Service.

Newchurch, E. J., A. L. Bachman, C. F. Bryan, D. P. Harrison, R. A. Muller, J. P. Newman, Jr., C. G. Smith, Jr., J. I. Bailey, Jr., G. G. Kelly, and K. C. Reibert. 1978. A Preliminary Environmental Assessment of Selected Geopressure-Geothermal Prospect Areas: Louisiana Gulf Coast Region, vols. 1 and 2. Institute for Environmental Studies, Louisiana State University, Baton Rouge.

Nguyen, V. T., J. F. Caskey, R. T. Pfundstein, and S. B. Rifkin. 1980. Geothermal Energy Environmental Problems and Control Methods. DOE/ET/27224-T1. U.S. Department of Energy, Division of Geothermal Energy. June.

Purtymun, W. D., R. W. Ferenbaugh, and W. H. Adams. 1981. Water Quality in the Vicinity of Fenton Hill, 1980. LA-9007-PR. Los Alamos National Laboratory, Los Alamos, N. Mex.

Reed, A. W., D. B. Hunsaker, Jr., R. D. Roop, and J. W. Webb. 1983. Evaluation of NEPA-Based Environmental Commitments at Four Geopressure Design Wells. ORNL/TM-8657.

Smith, L. L., Jr., and D. M. Oseid. 1972. "Effect of Hydrogen Sulfide on Fish Eggs and Fry." Water Res. 6, 711-20.

Thurow, T. L. and L. S. Cahn. 1982. Final Environmental Report: INEL Geothermal Environmental Program. EGG-2215. Prepared for the U.S. Department of Energy.

Thurston, R. V. and R. C. Russo. 1975. Quarterly Progress Report, October-December, 1975. Fisheries Bioassay Laboratory, Montana State University, Bozeman.

White, W. A., M. McGraw, and T. C. Gustavson. 1978. Environmental Analysis of Geopressure-Geothermal Prospect Areas, Brazoria and Kenedy Connties, Texas. Bureau of Economic Geology, University of Texas, Austin. 


\section{Appendix A \\ REFERENCE LIST OF ENVIRONMENTAL ASSESSMENTS FOR GEOTHERMAL PROGRAMS AND PROJECTS}

\section{Hydrothermal Energy Program}

1. ERDA. 1976. Environmental Assessment of the Hawaii Geothermal Project Well Flow Test Program. 75 pp.

2. ERDA. 1977. Environmental Impact Assessment: Hydrothermal Subprogram. EIA/GE/77-2. 287 pp.

3. DOE. 1978. Environmental Assessment: Raft River Geothermal Project Test Loop, Cassia County, Idaho. DOE/EA-0008. 129 pp.

4. DOE. 1978. Environmental Assessment: Coso Geothermal Project, Well Testing Activity, Exploratory Hole No. 1 (CGEH-1), China Lake, Inyo County, California. DOE/EA-0036. 50 pp.

5. DOE. 1979. Environmental Impact Assessment: Hawaii Geothermal Research Station, County of Hawaii, Hawaii. DOE/EA-0071. 97 pp.

6. DOE. 1979. Environmental Assessment: Raft River Geothermal Project Pilot Plant, Cassia County, Idaho. DOE/EA-0090. 108 pp.

7. DOE. 1980. Final Environmental Impact Statement: Geothermal Demonstration Program, 50-MW Power Plant, Baca Ranch, Sandoval and Rio Arriba Counties, New Mexico. DOE/EIS-0049. 746 pp.

8. DOE. 1980. Environmental Assessment: Geothermal Direct Heat Project, Marlin, Texas. DOE/EA-0117. 62 pp.

9. DOE. 1980. Environmental Assessment: Geothermal Direct Heat Geothermal Binary Cycle Demonstration Project, Imperial County, California. DOE/EA-0119. 298 pp.

Hot Dry Rock Energy Program

10. ERDA. 1977. Environmental Impact Assessment: Hot Dry Rock Subprogram. EIA/GE/77-6. $207 \mathrm{pp}$.

11. DOE. 1979. Environmental Assessment: Fenton Hill Hot Dry Rock Project Modification and Expansion, Sandoval County, New Mexico. DOE/EA-0091. $67 \mathrm{pp}$. 


\section{Geothermal Exploratory Drilling Program}

12. DOE. 1978. Environmental Assessment: Geothermal Exploratory Drilling Program, Eastern United States, Coastal Plain and Piedmont Provinces. DOE/EA-0015. 59 pp.

\section{Geopressured Geothermal Energy Program}

13. ERDA. 1977. Environmental Impact Assessment: Geopressure Subprogram. EIA/GE/77-3. 188 pp.

14. DOE. 1978. Environmental Assessment: Geothermal Energy, Geopressure Subprogram, GCO-DOE Pleasant Bayou No. 1, Brazoria Connty, Texas. DOE/EA-0013. 130 pp.

15. DOE. 1978. Environmental Assessment: Geothermal Energy, Geopressure Subprogram, Gulf Coast Well Testing Activity, Frio Formation, Texas and Louisiana. DOE/EA-0023, vol. 1. 401 pp.

16. DOE. 1978. Environmental Assessment: Geothermal Energy, Geopressure Subprogram, Gulf Coast Well Testing Activity, Frio Formation, Texas and Louisiana. DOE/EA-0023, vol, 2, Atlas, 14 pp.

17. DOE. 1978. Environmental Assessment: Geothermal Energy, Geopressure Subprogram, Lafourche Crossing No. 1, Terrebonne and Lafourche Parishes. Draft, 219 pp.

18. DOE. 1979. Environmental Impact Assessment: Geothermal Energy, Geopressure Subprogram, Southeast Pecan Island, Vermilion Parish, Louisiana. Draft, 185 pp.

19. DOE. 1980. Environmental Assessment: Geothermal Energy, Geopressure Subprogram, Sweet Lake No. 1, Cameron Parish, Louisiana DOE/EA-0065. 219 pp.

20. DOE. 1980. Environmental Evaluation: Dow Parcperdue Geopressure Project, Vermilion Parish, Louisiana. 59 pp.

21. DOE. 1980. Environmental Assessment: Geothermal Energy, Geopressure Subprogram, Gladys McCall Well Site, Cameron Parish, Louisiana. DOE/EA-0134. 189 pp.

22. DOE. 1981. Environmental Assessment: Geothermal Energy, Geopressure Subprogram, Gulf Coast Well Drilling and Testing Activity (Frio, Wilcox, and Tuscaloosa Formations, Texas and Louisiana). Draft, 85 pp. 


\section{Geothermal Loan Guaranty Program}

23. ERDA. 1976. Environmental Impact Assessment: Dry Creek Exploration Project Geothermal Loan Guaranty. Draft.

24. ERDA. 1976. Environmental Impact Assessment: Honey Lake Exploration Project Geothermal Loan Guaranty. Draft.

25. ERDA. 1977. Environmental Impact Assessment: Geothermal Loan Guaranty Application, Geothermal Food Processors, Inc., Churchill County, Nevada. EIA/GE/77-5. 65 pp.

26. ERDA. 1977. Environmental Impact Assessment: CU-1 Venture, Application for Geothermal Loan Guaranty (South Brawley Project). EIA/GE/77-7. 110 pp.

27. ERDA. 1977. Environmental Impact Assessment: CU-1 Venture, Application for Geothermal Loan Guaranty (Beryl and Lund, Utah). EIA/GE/77-8. 109 pp.

28. DOE. 1978. Environmental Assessment: Honey Lake Direct Heat Application Loan Guaranty Project. Draft.

29. DOE. 1978. Environmental Assessment: Roosevelt Hot Springs Field Development Geothermal Loan Guaranty Application, Milford, Utah Draft, 89 pp.

30. DOE. 1979. Environmental Assessment: Westmorland Development Project, Imperial Valley, California. DOE/EA-0058. 104 pp.

31. DOE. 1979. Environmental Assessment, Geothermal Loan Guarantee Program, Republic East Mesa Project, Imperial County, California. DOE/EA-0089. 121 pp.

32. DOE. 1980. Environmental Assessment: Oregon Trail Mushrooms. Geothermal Loan Guaranty Application, Malheur County, Oregon. DOE/EA-0013. 70 pp.

33. NCPA. 1980. Northern California Power Agency, NCPA No. 2, Geothermal Power Plant, Sonoma County, Final Joint Environmental Study. California Energy Commission, State Clearing House No. 78112021. 294 pp.

34. DOE. 1981. Environmental Assessment: Rorabaugh Lease Development Geothermal Loan Guaranty Application, Sonoma County, Califormia Draft, 89 pp.

35. DOE. 1981. Environmental Evaluation: Boise Geothermal Limited Geothermal Loan Guaranty Application, Ada County, Idaho. Draft, 36 pp. 


\section{Appendix B}

\section{OUTLINE OF GEOTHERMAL ENERGY ENVIRONMENTAL CONCERNS, MONITORING/MITIGATION MEASURES, AND AGENCY CONTACTS}

This outline presents a summary of major potential impacts that may be encountered in geothermal projects. It is intended to be useful to project managers and planners, especially in early stages of a project. For each heading, examples of potential concerns, mitigation and monitoring measures, and initial agency contacts are given. The list is not exhaustive, nor would all concerns and mitigation measures be applicable to a particular site. The outline is not a regulatory guide or summary of control systems, although these were considered in giving examples of mitigation measures and of contacts.

I. Airborne Emissions

A. Potential Concerns

1. Hydrogen sulfide: nuisance odor, possible long-term health effects

2. Boron: vegetation damage

3. Other gases and trace metals (e.g., mercury, arsenic, ammonia, methane, radon): health and vegetation effects

4. Salts (drift from cooling towers): vegetation damage

5. Fugitive dust (construction): important in PSDClass I areas

6. Climatic change (fogging and icing): short-term, local

B. Mitigation and Monitoring

1. Air quality baseline and operational monitoring often required

2. Control required for hydrogen sulfide (e.g, Stretford process), salt drift (drift eliminators) and dust (moistening and planting of surfaces)

3. Reduce climatic effects by including analysis of local meteorology in site selection

C. Contacts

1. U.S. Environmental Protection Agency

2. State, county, and regional air pollution officials

II. Noise

A. Potential Concerns

1. Well drilling, especially air drilling

2. Construction of facilities 
3. Operation (venting and stacking, breaks and blowouts, cooling towers, equipment)

B. Mitigation and Monitoring

1. Use of mufflers

2. Timing of activity

3. Siting to avoid sensitive receptors

C. Contacts

1. U.S. Environmental Protection Agency

2. State, local, or regional officials

III. Surface Water and Aquatic Ecosystems

A. Potential Concerns

1. Increased turbidity and sedimentation; deteriorating water quality; damage to aquatic life

2. Uncontrolled releases and spills; chemical and thermal damage to water quality and aquatic ecosystems

3. Hydrologic and ecological alterations from induced subsidence

4. Flow reductions in streams and hot springs

5. Water use (cooling, makeup for reinjection needs, hot dry rock systems) conflicts

6. Presence of threatened, endangered, or important species

7. Leaching of solid wastes

B. Mitigation and Monitoring

1. Determination of baseline water quality and value of aquatic habitat

2. Good construction practices to limit turbidity and sedimentation

3. Special surveys, structures, and buffer zones

4. Reinjection to limit surface disposal of liquid wastes; subsidence

5. Disposal of solid wastes in licensed disposal site

6. Monitoring of surface water chemistry

7. Use of existing roads, canals, pads, and other facilities when possible

8. Use of blowout preventers

9. Establishment of a spill prevention and countermeasure plan 
C. Contacts

1. U.S. Environmental Protection Agency

2. U.S. Fish and Wildlife Service, Endangered Species Office

3. State game and fish offices

4. State water quality offices

IV. Disturbance of Land Use and Terrestrial Ecosystems

A. Potential Concerns

1. Erosion and landsliding: loss of productivity

2. Cooling tower drift: damage to natural or agricultural ecosystems

3. Spills: thermal or chemical damage to ecosystems

4. Presence of prime or unique farmlands

5. Presence of threatened, endangered or important species

6. Presence of critical or unique natural habitats

7. Improper reclamation

B. Mitigation and Monitoring

1. Early mapping of habitat and land use during site selection to avoid impact

2. Special surveys, structures, and buffer zones for threatened, endangered, or important species

3. Good construction practices to limit erosion

4. Prompt revegetation

5. Geotechnical input to plant and well pad design to limit erosion and landsliding

6. Clustering wells to limit land use

7. Plant design to minimize escape of spills

8. Blowout preventers on wells

9. Use of existing roads and facilities when possible

C. Contacts

1. U.S. Fish and Wildlife Service, Endangered Species Office

2. State fish and game offices

3. U.S. Soil Conservation Service (prime and unique farmlands, erosion prevention, land use capabilities, revegetation, and reclamation) 


\section{B-4}

V. Groundwater Contamination

\section{A. Potential Concerns}

1. Leakage from well cases

2. Seepage from unlined pits

3. Spills

4. Lowered water tábles

5. Cross-connection of potable and nonpotable groundwater during drilling

B. Mitigation and Monitoring

1. Use of monitoring wells

2. Impervious liners in pits

3. Proper cementing of well casings

4. Use of blowout preventers

5. Design plant to limit escape of spills

C. Contacts

1. U.S. Geological Survey

2. U.S. Environmental Protection Agency

3. State water quality officials

VI. Geology

A. Potential Concerns

1. Subsidence: may result from withdrawal and injection of fluids

2. Induced seismicity: may result from withdrawal of fluids

B. Mitigation and Monitoring

1. Reinjection of spent fluids

2. Siting to avoid urban, agricultural, or industrial areas or important natural habitats

3. Establishment of benchmarks followed by periodic leveling surveys

4. Installation of microseismic monitors

5. Design of facilities to withstand earth tremors

6. Reduced pressure during reinjection

C. Contacts

1. U.S. Geological Survey 
VII. Solid Wastes

\section{A. Potential Concerns}

1. Sludge from descaling treatments

2. Drilling wastes (mud, cuttings, etc.)

3. Unsold by-products from $\mathrm{H}_{2} \mathrm{~S}$ or other control systems

4. Wastes from treating cooling water

5. Suspended soilds from fluids to be reinjected

B. Mitigation and Monitoring

1. Haul wastes to a landfill approved for the purpose

2. Sell by-products when possible

3. Use nonhazardous materials when possible

C. Contacts

1. U.S. Environmental Protection Agency

VIII. Cultural Resources

A. Potential Concerns

1. Destruction of historical, archaeological, or paleontological materials

2. Conflicts with native American religious sites

3. Reduction in flow of culturally significant hot springs and fumaroles

B. Mitigation and Monitoring

1. Careful site selection to avoid/minimize impacts

2. Surveys prior to construction

3. Preservation of materials discovered

C. Contacts

1. State Office of Historic Preservation

2. Native American representatives/leaders

3. Colleges, universities, museums, historical societies

IX. Community Resources

\section{A. Potential Concerns}

1. Local population increase

2. Inadequate community services and facilities (schools, hospitals, utilities, fire/police protection) 
3. Impacts to transportation systems

a. Increased traffic volume

b. Construction (pipeline, transmission line) in roadways

4. Aesthetic effects (plume visibility, facilities in scenic and pristine settings)

5. Noise (also see p. B-1) at residences, schools, hospitals, etc.

6. Land use changes (also see p. B-3).

B. Mitigation and Monitoring

1. Advanced planning to meet housing needs and services required by increased workforce

2. Carpooling, staggered work shifts to maintain existing traffic volume

3. Design of facilities (physical form, color) to complement the existing environment

4. Cooperation with local planning departments to ensure compatibility of land uses and to consider nuisances, such as odor or noise

C. Contacts

1. State, county; city officials

2. U.S. Dept. of Commerce, Dept. of Labor 


\section{INTERNAL DISTRIBUTION}

1-2. S. I. Auerbach

3. L. W. Barnthouse

4-5. C. R. Boston

6. R. S. Carlsmith

7. R. B. Craig

8-9. G. K. Eddlemon :

10. W. Fulkerson

11. W. F. Furth

12. C. C. Gilmore

13. S. G. Hildebrand

14. D. B. Hunsaker, Jr.

15. S. V. Kaye

16. J. F. McBrayer

17. C. H. Petrich
18-19. A. W. Reed

20. R. M. Reed

21. D. E. Reichle

22. V. R. Tolbert

23-24. J. W. Webb

25. D. J. Wilkes

26. H. E. Zittel

27-28. Central Research Library

29-43. ESD Library

44-45. Laboratory Records Dept.

46. Laboratory Records, ORNL-RC

47. ORNL Y-12 Technical Library

48. ORNL Patent Section

\section{EXTERNAL DISTRIBUTION}

49. Carl Austin, U.S. Navy, Geothermal Utilization Division, Naval Weapons Center, China Lake, CA 93555

50. Tilly Barling, U.S. Navy, Geothermal Utilization Division, Naval Weapons Center, China Lake, CA 93555

51. Richard Benson, Director, Office of Renewable Technologies, U.S. Department of Energy, CE-32, Rm. 5G 086, 1000 Independence Avenue, SW, Washington, DC 20585

52. Raymond P. Berube, U.S. Department of Energy, Office of Environmental Compliance, EP-361, 1000 Independence Avenue, SW, Washington, DC 20585

53. James C. Bresee, U.S. Department of Energy, Geothermal and Hydropower Technologies Division, CE-324, Rm. 5G 070, 1000 Independence Avenue, SW, Washington, DC 20585

54. Joseph F. Calabro, Pennsylvania Gas and Water Company, Water Quality Department, 135 Jefferson Avenue, Scranton, PA 18503

55. Frank.W. Childs, EG\&G Idaho, Inc., Energy Programs Division, P.O. Box 1625, Idaho Falls, Idaho 93515

56. Raymond Costello, U.S. Department of Energy, Geothermal and Hydropower Technologies Division, CE-324, Rm. 5G 070, 1000 Independence Avenue, SW, Washington, DC 20585

57. James C. Cotter, U.S. Department of Energy, Nevada Operations Office, P.O. Box 14100, Las Vegas, NV 89114

58. R. C. Dahlman, Carbon Cycle Program Manager, Carbon Dioxide Research Division, Office of Energy Research, Room J-311, ER-12, U.S. Department of Energy, Washington, DC 20545 
59. Edward Dickenson, U.S. Department of Energy, San Francisco Operations, Fossil, Geothermal and Solar, 1333 Broadway, Oakland, CA 94612

60. Myron Dorfman, Department of Petroleum Engineering, University of Texas, Austin, TX 78712

61. D. J. Feck, U.S. Department of Energy, Geothermal and Hydropower Technologies Division, 1000 Independence Avenue, SW, Washington, DC 20585

62. Carla Gerrard, U.S. Navy, Geothermal Utilization Division, Naval Weapons Center, China Lake, CA 93555

63. Fred Goldsberry; U.S. Department of Energy, Geopressure Project Office, 3 Northport Drive, Houston, TX 77060

64. Charles P. Groat, Louisiana Geological Survey, Louisiana State University, Highland Road, Baton Rouge, LA 70803

65. B. William Holman, U.S. Department of Energy, San Francisco Operations, Fossil, Geothermal and Solar, 1333 Broadway, Oakland, CA 94612

66. Frank F. Hooper, Ecology, Fisheries and Wildlife Program, School of Natural Resources, The University of Michigan, Ann Arbor, MI 48109

67. Elizabeth Jankus, U.S. Department of Energy, Office of Environmental Compliance, EP-361, RM. 4G 057, 1000 Independence Avenue, SW, Washington, DC 20585

68. A. J. Jelacic, U.S. Department of Energy, Geothermal and Hydropower Technologies Division, 1000 Independence Avenue, SW, Washington, DC 20585

69. Gary Kinsland, University of Southwest Louisiana, 100 East University Avenue, Lafayette, LA 70504

70. Fred Krieger, U.S. Department of Energy, San Francisco Operations, Fossil, Geothermal and Solar, 1333 Broadway, Oakland, CA 94612

71. P. A. LaBrie, U.S. Department of Energy, Geothermal and Hydropower Technologies Division, 1000 Independence Avenue, SW, Washington, DC 20585

72. Todd R. LaPorte, Professor, Political Science, Institute of Government Studies, University of California, 109 Moses Hall, Berkeley, CA 94720

73. Leon Lehr, U.S. Department of Energy, Geothermal and Hydropower Technologies Division, 1000 Independence Avenue, SW, Washington, DC 20585

74. David B. Lombard, U.S. Department of Energy, Geothermal and Hydropower Technologies Division, CE-324, RM. 5G 046, 1000 Independence Avenue, SW, Washington, DC 20585

75. John Meriwether, University of Southwest Louisiana, 100 East University Avenue, Lafayette, LA 70504

76. Helen McCammon, Director, Ecological Research Division, Office of Health and Environmental Research, Office of Energy Research, MS-E201, ER-75, Room E-233, U.S. Department of Energy, Washington, DC 20545

77. J. E. Mock, U.S. Department of Energy, Geothermal and Hydropower Technologies Division, 1000 Independence Avenue, SW, Washington, DC 20585

78. Harold A. Mooney, Department of Biological Sciences, Stanford University, Stanford, CA 94305

79. Robert Morton, Bureau of Economic Geology, University of Texas, Austin, TX 78712 
80. Laurence I. Moss, Energy/Environmental Design and Policy Analysis, 5769 Longs Peak Route, Estes Park, CO 80517

81. Robert E. Ogren, Biology Department, Wilkes College, Wilkes-Barre, PA 18701

82. William S. Osburn, Jr., Ecological Research Division, Office of Health and Environmental Research, Office of Energy Reseach, MS-E201, EV-33, Room F-216, U.S. Department of Energy, Washington, DC 20545

83. Ray Pelletier, U.S. Department of Energy, Office of Environmental Compliance, EP-362, Rm. 4G 047, 1000 Independence Avenue, SW, Washington, DC 20585

84. Paul R. Pike, Environmental Division, Union Electric Company, 1901 Gratiot, St. Louis, MO 63166

85. G. K. Redding, U.S. Department of Energy, Geothermal and Hydropower Technologies Division, 1000 Independence Avenue, SW, Washington, DC 20585

86. Irwin Remson, Department of Applied Earth Sciences, Stanford University, Stanford, CA 94305

87. Ronald Stearns, U.S. Department of Energy, Nevada Operations Office, P.O. Box 14100, Las Vegas, NV 89114

88. David Swan, Point Road, Wilson Point, S. Norwalk, CT 06854

89. Virginia Van Sickle, Louisiana Geological Survey, Louisiana State University, Highland Road, Baton Rouge, LA 70803

90. Ronald S. H. Toms, U.S. Department of Energy, Geothermal and Hydropower Technologies Division, 1000 Independence Avenue, SW, Washington, DC 20585

91. Susan S. Waddle, Oak Ridge Operations, P.O. Box E, U.S. Department of Energy, Oak Ridge, TN 37831

92. Robert L. Watters, Ecological Research Division, Office of Health and Environmental Research, Office of Energy Research, MS-E201, ER-75, Room F-226, U.S. Department of Energy, Washington, DC 20545

93. William H. Williams, Division Manager, American Bell, Building 83, Room 1B23, 100 Southgate Parkway, Morristown, NJ 07960

94. Frank J. Wobber, Division of Ecological Research, Office of Health and Environmental Research, Office of Energy Research, MS-E201, U.S. Department of Energy, Washington, DC 20545

95. Robert W. Wood, Director, Division of Pollutant Characterization and Safety Research, U.S. Department of Energy, Washington, DC 20545

96. Office of Assistant Manager for Energy Research and Development, Oak Ridge Operations, P.O. Box E, U.S. Department of Energy, Oak Ridge, TN 37831 97-123. Technical Information Center, U.S. Department of Energy, Oak Ridge, TN 37831 